\title{
wiiw
}

\section{JANUARY 2019}

\section{Working Paper 161}

\section{Dying Light: War and Trade of the Separatist-Controlled Areas of Ukraine}

Artem Kochnev

The Vienna Institute for International Economic Studies Wiener Institut für Internationale Wirtschaftsvergleiche 



\title{
Dying Light: War and Trade of the Separatist- Controlled Areas of Ukraine
}

\author{
ARTEM KOCHNEV
}

Artem Kochnev is PhD student at Johannes Kepler University (JKU) Linz and at the University of Innsbruck (UIBK), Austria.

The author thanks Francisco Litvay for providing access to the GIS software, and participants of the research seminars at the Vienna Institute for International Economic Studies and the University of Innsbruck for helpful comments. Special thanks go to Alexei Kochnev for fruitful discussions. 



\section{Abstract}

The paper investigates how war and the war-related government policies affected economic activity of the separatist-controlled areas of Ukraine. The paper applies a quasi-experimental study design to estimate the impact of two events on the separatist-controlled areas: the introduction of the separatist control and the introduction of the second round of the trade ban, which was imposed by the government of Ukraine on the separatist-controlled territories in 2017. Using a difference-in-difference estimation procedure that controls for the yearly and monthly effects, individual fixed effects, and the region-specific time shocks, the study finds that the separatist rule decreased the economic activity by $38 \%$ in the Donetsk region and $51 \%$ in the Luhansk region according to the preferred specifications. At the same time, the trade ban of the year 2017 against the major industrial enterprises of the separatist-controlled areas decreased luminosity by $20 \%$. The paper argues that the trade disruptions due to the war actions were nested within the negative effect of the separatist rule and accounted for half of it.

Keywords: costs of war, satellite data, trade, Ukraine crisis, political economy

JEL classification: D74, E01, E20, F51 



\section{CONTENTS}

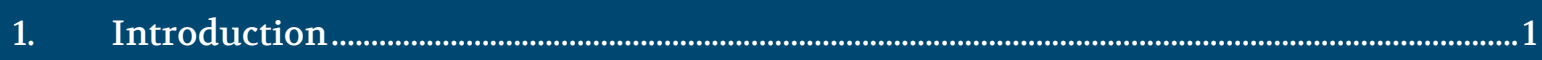

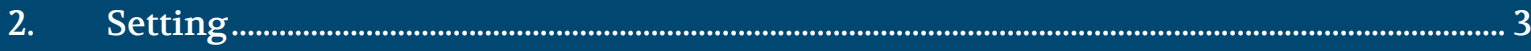

2.1 Context of the Conflict and the Territorial Control ....................................................

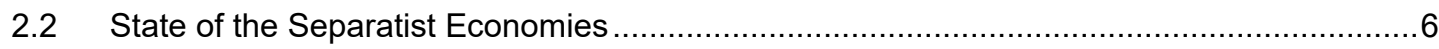

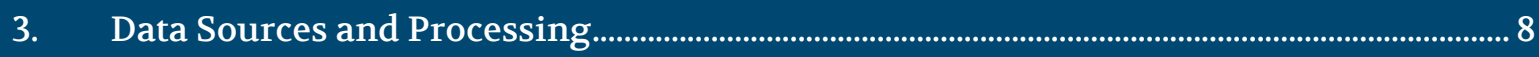

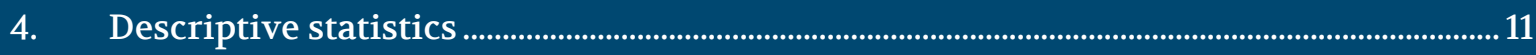

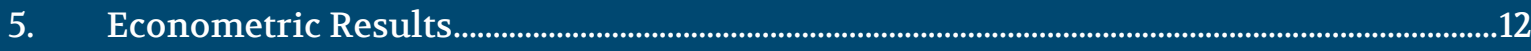

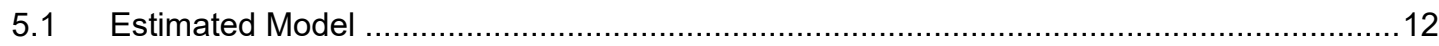

5.2 Difference-in-Difference Estimates of the Separatist Control ....................................... 14

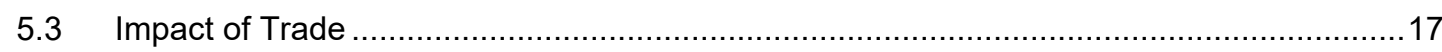

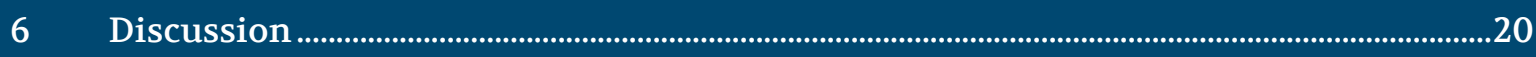

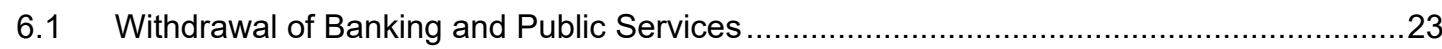

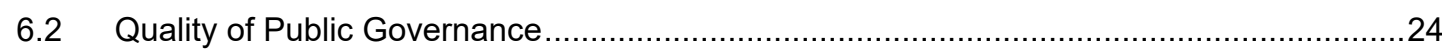

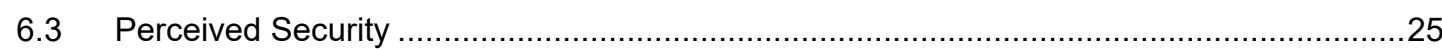

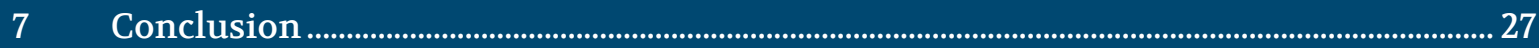

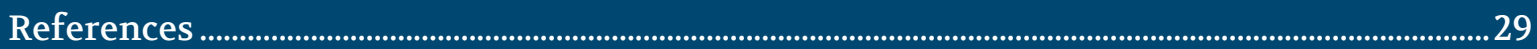

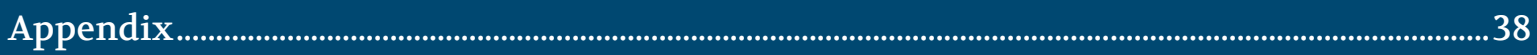

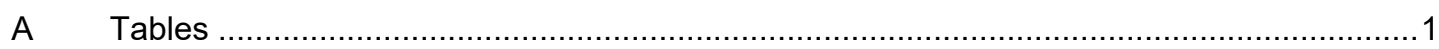

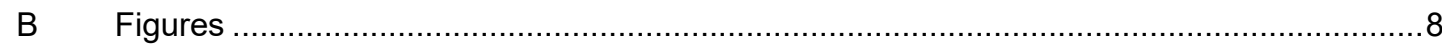




\section{TABLES AND FIGURES}

\section{Appendix}

Table 1: Economic Characteristics of the $55 \mathrm{~km}$ Urban Areas of Governmentand

Separatist-controlled Areas in Donetsk Prior to the War

Table 2: Economic Characteristics of the $55 \mathrm{~km}$ Urban Areas of Governmentand

Separatist-controlled Areas in Luhansk Region Prior to the War ....................................... 1

Table 3: Descriptive Statistics Before and AtWar, Donetsk Region ................................................. 2

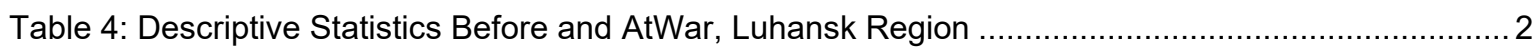

Table 5: Impact of the Separatist-Control on Luminosity, Monthly Based ............................................ 3

Table 6: Impact of the Separatist-Control on Luminosity, No Districts at the Contact Line,

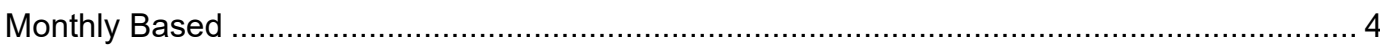

Table 7: Impact of the Separatist-Control on Luminosity: 20-40 km away from the Contact Line,

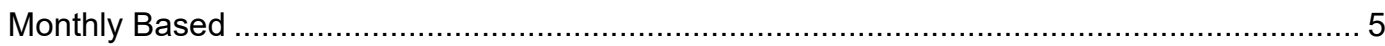

Table 8: Change of Luminosity in the DNR-controlled areas after the Trade Ban by Controls,

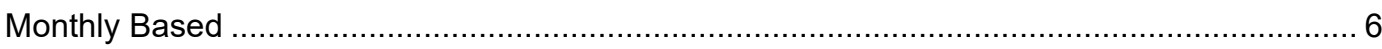

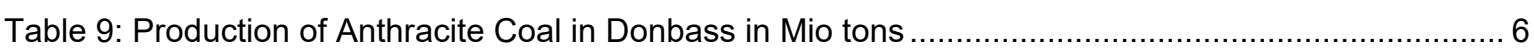

Table 10: Impact of the Separatist-Control on Luminosity, Monthly Based .......................................... 7

Figure 1: Graphical Abstract. Difference in Luminosity of the Donetsk and Luhansk Regions between

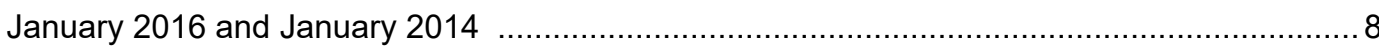

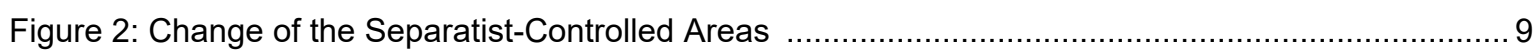

Figure 3: Luminosity of the Donetsk surroundings in January of 2014 - 2017 years ............................ 10

Figure 4: Change of the mean log luminosity in the Donetsk region by quarter and controlling party .... 10

Figure 5: Change of the mean log luminosity in the Luhansk region by quarter and controlling party .... 11

Figure 6: Urban areas within $3.5 \mathrm{KM}$ of location of nationalized firms ............................................ 12

Figure 7: Change of the mean log luminosity in the separatist-controlled region of Donetsk

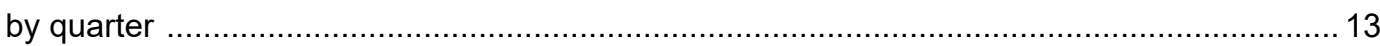

Figure 8: The Number of Internally Displaced Persons and Battle Events in the Cities Populated

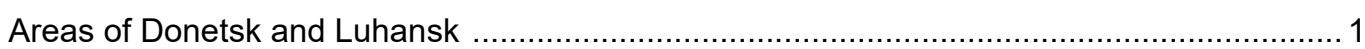




\section{Introduction}

After years of studying countries at war, economists barely have doubts about the general effect the conflicts have on the economies. It's bad.1 Yet, the question "how bad?" remains open. As Smith (2014) and Blattman and Miguel (2010) emphasize, lack of credibility of the cross-country studies and difficulties in unequivocally defining what to count as conflict costs are just two basic reasons why the discussion is going on. To achieve greater credibility, researchers started to focus on specific channels, through which hostilities affect economic outcomes (Blattman and Miguel (2010) and Mueller (2013) provide comprehensive surveys). In doing so, however, the field seemed to pay little attention to the relative importance of the different channels and the way they contribute to the aggregated decline of economic activity. Even after assuming a perfect external validity, of the micro-studies, it remains unclear how one can compare the findings of Besley and Mueller (2012) on the change in house prices due to terrorist attacks or decline in trade volumes caused by civil war in Martin, Mayer and Thoenig (2008) to the aggregated GDP loss estimated by Abadie and Gardeazabal (2003).

Lack of attention to the question might lead to a misinterpretation of the commonly observed patterns such as a rapid economic recovery that usually follows the end of the war. For instance Blattman and Miguel (2010) propose the neoclassical model of economic growth as a unifying framework, where a war introduces a negative shock to the capital stock, which recovers quickly due to an assumption of a technology-augmented labor force. But the production might stop during the war due to indirect effects: for instance, because the hostilities destroyed the transport infrastructure or because agents are reluctant to transport the already produced goods to their customers because of the insecurity. In the case, the war affects the economy as a trade tariff. An increase in the costs of trade, not the destruction of physical assets, would be a major factor that contributes to the decline of economic activity. It is important to distinguish between the two effects

\footnotetext{
${ }^{1}$ The point of view finds support in numerous empirical studies on a macro (Collier et al., 2003: Garfinkel and Skaperdas, 2012: Brauer and Dunne, 2012) and a micro scale (Blattman and Miguel, 2010 Ray. 2010).
} 
because it implies different policy responses. In the case of the capital depletion, one needs to provide finance to private agents to restore physical assets. In the second case, the government should focus on recovering public infrastructure, restoring confidence, and guaranteeing security.

In the current study, I address the issue using the context of a large-scale separatist insurgency in Eastern Ukraine to disentangle several channels of the conflict-related costs using a quasi-experimental setting as a foundation for the difference-in-difference estimator. I start by estimating the impact of the separatist territorial control on the nighttime luminosity of the urban areas. After that, I try to disentangle the effect by using an exogenous exploiting the effect of a trade shock introduced by the government's trade ban with the separatist territories. The point estimates in the preferred specification imply that the trade ban reduced luminosity in a range between $-20.3 \%$. The estimate constitutes roughly half of the negative impact induced by the separatist control. I argue, therefore, that the increase in trade costs accounted for roughly one-half of the luminositydecline in the separatist-controlled areas. Additionally, I investigate other events that could cause a negative impact on the economic performance: break-up with Ukraine's banking sector, withdrawal of the public services and social security payments and worsening quality of public governance. I find no evidence that any of the channels had a statistically significant impact on the luminosity levels in the separatist-controlled areas. In line with Besley and Mueller (2012) and Ksoll, Macchiavello and Morjaria (2009), the paper argues that the puzzle is most likely to be explained by negative expectations of the agents prior to the active policy interventions by Ukraine's government.

The study contributes to several strands of literature. First, it enhances the literature on the economic costs of conflict by highlighting how the war affects economic activity by impeding trade and shows how much it could account for an aggregate loss in economic activity (Mueller, 2013; Amodio, Baccini and Di Maio, 2017). Second, it provides a new application for using satellite data as a proxy for economic activity in war-torn regions (Chen and Nordhaus, 2015, Li and Li, 
2014; Li et al., 2017). Third, it gives a first systematic account on assessing the costs of conflict in Ukraine, which got - given its size and intensity - limited attention in the economic literature with an exception of just several contributions (Zhukov, 2016; Coupe, Myck and Najsztub, 2016; Gorodnichenko and Talavera, 2016; Mirimanova, 2017; Makarin and Korovkin, 2018).

\section{Setting}

\subsection{Context of the Conflict and the Territorial Control}

The Donetsk People's Republic (DNR) and the Luhansk People's Republic (LNR) are two unrecognized states that are located on the territories of Donetsk and Luhansk respectively $\left.\right|^{2}$ The region, commonly referred as Donbass, was a highly industrialized region with 6 million people living there prior to the war (see Figure D.1 for the exact location of the unrecognized states). $4^{4}$ DNR and LNR proclaimed their independence from Ukraine in Mai 2014, two months after the protest opposition in Kiev overthrew the administration of the previous president of Ukraine, Viktor Yanukovich. See Figure 2 for the territory controlled by the insurgents.

The immediate roots of the separatist insurgency in Eastern Ukraine trace back to the results of the confrontation between the president Yanukovich and the protest opposition, whose leaders demanded to stop political repressions and continue the process of Eurointegration (Kyivpost.com, 2013b).$^{5}$ By the end of February 2014, the protests resulted in hostilities between the demonstrators and

\footnotetext{
${ }^{2}$ There is no consensus about how to properly refer to the DNR and LNR republics. The truce on February 12th, 2015 does not contain any references to DNR and LNR in the texts. The leaders of DNR and LNR, who signed the truce, do not have any formal status in the documen ${ }^{3}$ (OSCE) 2015). Media tended to strategically select labels of the DNR/LNR armed supporters to appeal to a certain connotation: Ukrainian media frequently called them terrorists ("boyoviks") (Segonya.ua, 2014), militants, and Russian occupation troops (UNIAN, 2017) whereas, Russian media tended to call them rebels ("povstanci") (RBK, 2014a) and militiamen ("opolchency") (RIA, 2018). This paper calls them "separatists" following BBC (2014a) although the term might not carry the 'neutral' representation.

${ }^{4}$ Media and public persons frequently use the term 'Donbass'. Donbass is a name for a coalmining region in the contemporary East-Ukraine with no strict borders. Media, however, use the name as a shortcut for the Donetsk and Luhansk administrative regions together. I follow the convention in my paper as well.

${ }^{5}$ See the complete breakdown of the major events in Appendix $\mathrm{C}$.
} 
the state security forces with at least 88 dead people (BBC, 2014a). After signing a political agreement with the opposition next day, Yanukovich fled from the country and was dismissed from his duties by the Parliament on February 22nd.

Despite wide support of the interim government in Kiev, the elites faced a series of the pro-Russian rallies in East Ukraine starting from early March. Starting as peaceful rallies, it turned into an armed rebellion when a group of insurgents under command of Igor Girkin - led by the group of "volunteers" from Russia - stormed police headquarters and set up checkpoints in the city of Sloviansk in the North of the Donetsk region (Rachkevych, 2014). The actions motivated the interim government to launch a military operation in East Ukraine.

The contemporary territorial control between the separatists and the government was barely predictable at the beginning of the war. Ukraine's Government expected to eliminate insurgents immediately but the military operation launched on April 15th stalled quickly (Smith-Spark and Morgan, 2014; BBC, 2014a). The separatists, on the contrary, expected an intervention from Russia similar to the Crimean case and planned to spread their territorial control to the other Eastern and South-Eastern regions of Ukraine. According to the military leader of the insurgency, it was "a shock" when insurgents realized it is not going to happen:

We thought that the Russian administration will come, Russia will organize the rear and there will be a new republic within Russia. And I did not think about any kind of state-building. But later, when I realized that Russia will not absorb us (I associated myself with a militia) - the decision was a shock for us. (Zavtra.ru (2014))

The conflict outcome was particularly dependent on the ambiguous positions of Russia and the foreign countries involved in the conflict resolution (Pravda.com.ua, 2014). By August 2014, the rapid advances of the State troops forced the insurgents' groups to leave the initial areas of the armed insurgency and move into the regional capitals: Donetsk and Luhansk (see the upper panel of Figure 2). Girkin stated that August was the critical month for the insurgency. Government forces 
encircled the insurgents, which lacked provision and firearms:

In August - at the peak of the crisis - we fought almost in an agony. We simply tried to fix the holes [in the defense - A.K.] and military breakthroughs. We were completely encircled and could not break through. [...]

I am accused of intending to leave Donetsk. To be honest, at a certain point I stopped to believe that support from Russia would come at all. I just stopped to believe! And nobody could guarantee me that. (Zavtra.ru (2014))

The situation changed in the last week of August when insurgents suddenly got reinforcements, whose background remains disputed. The insurgency backup helped to encircle several government military units and expanded the front line to the south of Donetsk, which separatists had not controlled before (see the bottom-left panel of Figure 2). By September 5th, the territorial control largely took the form of the area close to a contemporary one (as of May 2018) with an exception of the Debaltsevo settlement, which was taken over by separatists in February 2015. By February 2015, representatives of both sides signed the truce that regulated the peace process and implicitly settled the areas of the territorial control between the parties. After the end of February 2015, no large changes in territorial control occurred. Although the war intensity seemed to decline after signing the second Minsk agreement - a diplomatic document that established a framework for diplomatic negotiation between the government and separatists in February 2015 - armed skirmishes, explosions, and shell bombings continue to happen regularly with varying intensity (OSCE.org, N.d.: Chernenko, 2018).

As of May 2018, separatists controlled around 30\% of the Donbass area: the territory similar to the size of Northern Ireland and Israel $]^{6}$ Although there is no readily available official statistics at a fine spatial resolution, the indirect assessments based on the GAR dataset (De Bono and Chatenoux, 2015) show that the

\footnotetext{
${ }^{6}$ The estimated area of the territorial control of separatists - based on the georeferenced maps by the author - is 16.5 thousand sq. km. The area of Northern Ireland is around 14.1 thousand sq.km., for Israel: 20.8 sq.km.
} 
basic economic characteristics (such as the average number of people living in urban areas and capital stock per capita) are statistically indistinguishable between the separatist- and government-controlled areas at the level of $5 \times 5 \mathrm{~km}$ cells.

\subsection{State of the Separatist Economies}

Prior to the war, the regions were part of a regional industry cluster of Ukraine with a highly urbanized population. Donetsk and Luhansk regions specialized in mining industries and accounted for $25 \%$ of total exports and $15 \%$ of the total GDP of Ukraine (Havlik and Astrov, 2014). With the notable exceptions of Coupe, Myck and Najsztub (2016), Mirimanova (2017), and Gorodnichenko and Talavera (2016), there was little academic contributions devoted to the state of the separatist economies. The major source of evidence comes therefore from journalistic investigations. Some of the widely mentioned war-related factors that contributed to the shrinkage of the economies are destruction of physical capital, mass emigration and market disintegration (Golovatjuk, 2017; BBC, 2015a; Gorodnichenko and Talavera, 2016; Mirimanova, 2017; Golunov and Artemev, 2015; Skorik, 2017).

Additionally, Ukraine's and Separatists' governments introduced a number of policies that should have had a negative impact on the local economies. The policy changes are of particular importance because they allow for hypothesis testing. Here is the list of the ones I exploit in the paper:

- December 1st, 2014: The government of Ukraine introduces a ban on banking operations in the separatist territories, stops social security payments and withdraws all Government services from the separatist-controlled areas (Walker, 2014).

- January, 2015: Separatists start to re-register enterprises within their own 'legal space' (Golunov and Artemev, 2015).

- January 16th, 2015: The government of Ukraine introduces a trade ban on the occupied territories except for strategically important products. Major 
industrial enterprises continue to operate (Rada.gov.ua, 2014).

- January 25th, 2017: Ukrainian activists block several roads and railways to stop the remaining trade between the mainland Ukraine and the enterprises of the separatist areas (Euromaidanpress.com, 2017b).

- March 3rd, 2017: Separatist authorities introduced an "external administration" at 46 companies previously operating in the Ukrainian legal space (43 in DNR, 3 in LNR). Company owners called the process a nationalization (Euromaidanpress.com, 2017a).

- March 16th, 2017: The government of Ukraine imposes a complete ban on the cargo movement to the separatist-controlled areas (Euromaidanpress.com, 2017).

Despite the attempts of the government of Ukraine to isolate DNR and LNR economies, there are several channels that kept them connected with both the Ukrainian and external markets. Until 2016, the government-controlled areas of Donetsk and Luhansk continued to supply both water and electricity to the DNR and LNR consumers with little to no payments in return (Kirillov, 2017). Apart from that, the biggest DNR/LNR enterprises continued to operate in the Ukrainian legal space - until their de-facto nationalization in March 2017 - supplying goods to the Ukrainian 'mainland' and refusing to pay taxes to the separatist 'authorities' (Golunov and Artemev, 2015; Skorik, 2017).

Media investigations reported that Russia supplies gas and electricity energy to the region and finances the overwhelming part of the local state budgets (Fadeeva and Serkov, 2018; Golovatjuk, 2017; Golunov and Artemev, 2015). Journalists also mention that some DNR/LNR enterprises sell their goods across the Russian border or establish/use firms in Russia to export goods to the third countries (Golunov and Artemev, 2015: BBC, 2015a; Golovatjuk, 2017).

One particular feature of the region was the prevalence of vertically integrated companies that possessed business assets in various parts of the regions. A dense railway network served to establish dense value chains between mines, manu- 
facturing enterprises, and harbors. The Minsk-II agreement left parts of the enterprises on either side of the contact line: most of the coal producing mines fell under control of separatists, whereas the major coal consumers (mainly the thermal power stations) and the city of Mariupol, which has the only harbor in the region to ship goods for export, are located in the government-controlled areas. The split imposed a break-up of the traditional value chains forcing the companies either to find alternative supply routes or set the production sites idle DTEK (2015, 2016); Metinvest (2015).

The aforementioned factors - the remaining connections with the rest of Ukraine, negative spillover effects and the incomplete isolation from the external markets - will have implications on the direction and the size of the bias of the estimators in the regression analysis. I discuss and address the issues in section 5 .

\section{Data Sources and Processing}

I use two major data sources in my analysis. The first one is the nighttime satellite images of Earth provided by NOAA (2018). I process the images and calculate the values of the nighttime luminosity, which I use as a proxy for economic activity. As Henderson, Storeygard and Weil (2012) and Chen and Nordhaus (2015) argue, luminosity can be a suitable proxy for GDP in certain cases. Albeit the nighttime lights are prone to measurement error, there are several reasons to use them in the study. First, it is one of the few ways to measure the state of economies in the regions with absent manually produced statistics. Both economists and geographers applied them in a variety of contexts from measuring poverty (Pinkovskiy, 2017; Pinkovskiy and Sala-i Martin, 2014) and studying the effect of international sanctions (Lee, 2018) to estimating the economic costs in the war-afflicted areas (most notably in the context of the civil war in Syria (Li et al., 2017; Li and Li, 2014; Witmer and O'Loughlin, 2011) and in a short note with an application to Ukraine by (Coupé and Obrizan, 2016)). Second, contrary to the standard national accounts, they cannot be manipulated. At last, the nighttime lights allow extracting spatially referenced information at a more detailed scale than tradi- 
tional data sources, allowing to perform analysis beyond the observational units defined by the administrative borders and increase the number of observations in the sample.

In the study, I use the VIIRS cloud-free satellite images of NOAA (2018) to compute luminosity in Ukraine at the level of individual cells with the size of $0.01 \times 0.01$ degrees (approximately $0.605 \mathrm{sq} . \mathrm{km}$ at the 48 degrees of latitude, where Donetsk - the largest city of the region - is located)..$^{7}$ Unfortunately, images for Ukraine are available from October to March only as sunshine in other months compromises images in the other months of the year. Thus for each year, I am able to track luminosity for half of the year with a gap between March and October.

The VIIRS nighttime images are considered to be superior compared to the previously used DMPS-OLS satellites in several respects: the sensor does not saturate, performs an onboard calibration of the images, has a finer resolution and has a constant effective instantaneous field of view that prevents blurring dark pixels by the light ones (Elvidge et al. 2013). Yet the finer resolution has its drawbacks. VIIRS tends to capture lights that are temporal in nature and might not be caused by human productive activity (fires, flares, boat lights etc). To mitigate the problem, I extract only the cells within the urban areas of Ukraine only. I utilize the MODIS shapefile as a mask to define the urban areas, split them into a cell grid and extract the mean cell luminosity for each month available from January 2013 to December 2017 $]^{8}$ Moreover, some of the image cells have negative values due to the calibration of the images. The processed cells within the urban areas of Ukraine spanning from January 2013 to December 2017 contain 1352 (out of 746796 cells) observations with negative values. I set the values of the images equal to zero. As some of the cells were split by the mask of the urban areas, I

\footnotetext{
${ }^{7} 1$ degree contains 100 arc-minutes or 3600 arc-seconds. The area on the surface of the Earth assuming it is a perfect circle - is calculated according to the following formula: $S=(m \times \cos (d) \times$ $N)^{2}$, where $S$ is the square, $s$ is the distance measured in arc-minutes, $d$ stands for a degree of an angle, and $N$ is a value of a nautical mile. In the case, $m=0.6$ (because 0.01 degree contains 36 arc-seconds), $d=48$, and $N=1852 \mathrm{~m}$.

${ }^{8}$ The MODIS dataset uses a machine learning algorithm to classify Landsat imagery of the year 2002 into urban and rural areas. The predictive power of the classification on the test sample is $90 \%$. See Schneider, Friedl and Potere (2009) for details of the methodology.
} 
delete cells with an area less than 551000 sq. meters - the minimal resolution of the VIIRS sensor - to keep observations with a comparable image quality only. ${ }^{9}$ Tables E.1, E.2, E.3, E.4 in Appendix E summarize the differences in the distribution of the variables after the changes of the dataset.

As a result, I obtain two balanced panel datasets with gaps between March and October that contain mean monthly luminosity of the urban cells of Ukraine. The first one spans from January 2013 to March 2016 and covers the total urban area of Ukraine (Table E.2). I use it to estimate the impact of the separatist control on the economy. The second one spans from January 2016 to December 2017 and contains the cells of the separatist territories only. I use the dataset to analyze the impact of the trade ban, which was effectively imposed first by activists in February 2017 and then established by the government since March 2017 (Table E.4).

To control for battle events, I use the 'Cross-sub' battle events dataset for the Ukrainian conflict (Zhukov, Davenport and Kostyuk, 2017) that was first introduced by Zhukov (2016). Specifically, I use the district-level number of recorded violent events (coded as All violence in the regression tables): protests, selective violence (e.g. small arms), indiscriminate violence (e.g. artillery and air strikes). The dataset has several advantages compared to the other available alternative datasets: it is collected by using a support vector machine classifier enabling to analyze the media messages faster and at a greater scale compared to the manual processing, Zhukov uses his own training and test dataset collected specifically for the study on Ukrainian conflict, the dataset is collected using the media reports from both Ukrainian, Russian and English-speaking sources minimizing the media bias (see Zhukov (2016) for more details on the data collection process).

I use the district level borders of Ukraine from the GADM Project as of August 2015 (Hijmans, Garcia and Wieczorek, 2015) and digitized the contact line using the map that was apparently used for negotiations during the first Minsk agreement (UNIAN, 2015) adjusted for the advances of the separatists since then

\footnotetext{
${ }^{9}$ The minimal resolution of the satellite at nadir - point on the Earth's surface orthogonal to the location of a satellite - is $742 \times 742=550564 \mathrm{~m}$.
} 
using the manually georeferenced map of Ukraine's ministry of defense (Mediarnbo.org, 2018).

To investigate the impact of the trade ban in 2017 on the luminosity in separatist republics, I georeferenced the locations of the industry and mining enterprises (from the list of Euromaidanpress.com (2017a)), to which the ban became applicable and presumably had a high share of labor in production (see the full list in Table C.1). Each cell within $3.5 \mathrm{Km}$ away from any of the enterprises was assigned I counted as to be affected by the trade ban.

\section{Descriptive statistics}

Tables 3, 4 provide the first glance at the changes occurred to the luminosity in Donetsk and Luhansk regions. Comparison of the means reveals that the luminosity of the separatist-controlled areas declined stronger than in the ones controlled by the state forces.

The change of logarithm of luminosity declined in DNR areas from -0.519 to -0.99 vs -0.717 to -0.803 in the state-controlled ones of the Donetsk region $(-0.916$ to -1.537 in LNR vs -0.846 to -1.871 for the state-controlled areas of the Luhansk region). One has to keep in mind, however, that the variation of the luminosity cells is too great to claim that the results are statistically different from each other. Yet, as the subsequent regressions will demonstrate, accounting for time and individual fixed effects support the conclusions that follow from the changes in the means.

Figure 3 demonstrates the evolution of luminosity in the surroundings of Donetsk - the largest urban area of the region ${ }^{10}$ - in January of the four consecutive years from 2014 to 2017. One can clearly see how the luminosity drops from 2014 to 2015 and recovers in the later years.

One may notice a similar pattern for the aggregated change of the log of quarterly luminosity over the observed period of time. Figures 4,5 and D.2 give a

\footnotetext{
${ }^{10}$ The pre-war population was close to 1 million inhabitants $(1 / 6$ of the whole Donbass region and $2 \%$ of Ukraine's total as of 2011.
} 
sense of the relative differences in nighttime luminosity for the government- and separatist- and Russia-controlled areas from 2013 to 2016.

Notice that in the case of Donetsk and Luhansk (to a somewhat lesser extent though) both government- and separatist-controlled areas show similar trends prior to the conflict with a change of the trajectory thereafter. The separatistcontrolled cells, however, show a greater decline and a slower recovery than the government-controlled ones. Yet the luminosity dynamics of Crimea - whose economy did not experience an armed confrontation, showed the same dynamics up to the last quarter of 2015 when the electricity supply from Ukraine to the peninsula was stopped (Fadeeva and Serkov, 2018).

\section{Econometric Results}

\subsection{Estimated Model}

To estimate the impact of the separatist regimes on the economies, I apply a difference-in-difference estimator assuming the following model:

$$
\begin{array}{r}
\ln (\text { lum })_{i, d, r, t}=\beta_{0}+\beta_{1} \times \mathrm{DNR}_{i} \times(\text { Post April 2014) })_{t}+\beta_{2} \times \mathrm{LNR}_{i} \times(\text { Post April 2014) })_{t}+ \\
\beta_{3} \times(\text { Battle Events })_{d, t}+\boldsymbol{\rho} \cdot \boldsymbol{i d}+\boldsymbol{\tau} \cdot \boldsymbol{t}+\boldsymbol{\delta} \cdot \boldsymbol{r} \boldsymbol{t}+\varepsilon_{i, t}
\end{array}
$$

Where $\ln (\operatorname{lum})_{i, d, r, t}$ is luminosity of a cell $i$, in a district $d$, region $r$, and time $t$; $\mathrm{DNR}_{i} \times(\text { Post April 2014) })_{t}$ and $\mathrm{LNR}_{i} \times(\text { Post April 2014) })_{t}$ are interaction terms that take value 1 in case the cell $i$ fell under control of the DNR or LNR separatists, which changed at a date $\bar{t}$, (Battle Events) ${ }_{i, t}$ stands for a number of the districtlevel battle events in a cell $i$ at a period $t, \boldsymbol{r}$ and $\boldsymbol{t}$ are vectors of dummies for individual and time fixed effects for every cell $i$ and time $t$ respectively, $\boldsymbol{r} t$ is the vector of interaction terms between a region $r$ and time $t$ such that the number of regions $r$ is strictly less than the number of cells $i{ }^{11}$ The coefficients $\beta_{1}$ and $\beta_{2}$ present the major interest of the studies because they show the effect of the

\footnotetext{
${ }^{11}$ Stated more formally $\boldsymbol{r} \boldsymbol{t}=\left[r_{1} t_{1}, r_{1} t_{2}, \ldots, r_{1} t_{t-1}\left|r_{2} t_{1}, r_{2} t_{2}, \ldots, r_{2} t_{t-1}\right| \ldots \mid r_{r} t_{1}, r_{r} t_{2}, \ldots, r_{r} t_{t-1}\right]$.
} 
separatist control on the luminosity of a cell $i$.

A potential pitfall of the estimation procedure is the violation of the stable unit treatment variable assumption, which may appear in the results of the present study in two ways.

'Cross-border' migration is the first cause for concerns. Despite the restrictions on the movements of people and goods imposed by Ukraine's Government in January 2014, the population of Donetsk and Luhansk could massively migrate away from the separatist territories at the early stages of the conflict and could potentially increase the light intensity in the government-controlled areas. It is hard to verify, to which extent migration affected the luminosity as there is not enough data to make reliable estimations ${ }^{12}$

Another potential pitfall is related to the existing economic ties between the urban economies. Cities in close proximity could have strongly integrated economies. Thus, the shocks introduced in the separatist-controlled areas could have a negative spillover effect on the government-controlled areas blurring the difference between the treatment and control group. Gorodnichenko and Talavera (2016) pointed out that the price movements for a basket of basic consumption goods in government-controlled areas move differently compared to prices in the separatist-controlled areas of Donetsk region indicating a weak market integration between the regional economies. Nonetheless, their analysis covers the time span from October 2015 to March 2016 and their conclusions might not apply to the early stages of the conflict. Yet even if the spillover effects would take place, the estimates would be biased toward zero as the negative shock would propagate in the neighboring regions (attenuation bias). Thus in case of the statistically significant coefficient, the point estimate would be of a lesser magnitude than the counter-factual providing a stronger argument in favor of the causal effect.

I address both of the issues in three ways. To account for spatial spillovers, I estimate the model with time-specific regional shocks (an interaction term between the dummy of a region and a time dummy) similar to the approach demon-

\footnotetext{
${ }^{12}$ On the other hand, the large-scale conflicts usually ignite mass migration, which is a natural reaction to insecurity and is hard to prevent once the conflict started. Therefore, the migrationbiased estimations could be of greater interest for the decision-makers.
} 
strated by Dube, Lester and Reich (2010) with an exception that I allow for greater flexibility of the shocks without restricting them to individual linear trends only. This type of modeling should account for idiosyncratic shocks that happened for all cells in a region $r$ in a time period $t$. First, I estimate the model with two restricted samples. One subsample excludes the cells that contain a segment of a contact line. The second one restricts the sample to the cells that are located 20-40 KM away from the contact line. The purpose of the sample restriction is to pickup cells that are similar in characteristics but are less likely to be affected by the spillover effects due to as they are more distant from each other than the direct neighbors.

\subsection{Difference-in-Difference Estimates of the Separatist Control}

Table 5 presents the baseline results. It estimates the impact of the separatist control on the nighttime luminosity for three samples: column All estimates the difference for all regions of Ukraine, column East Ukraine estimates using cells of five most-eastern regions only ${ }^{13}$, column Donbass estimates using urban areas of Donetsk and Luhansk regions only. The benchmark result is the estimates performed for the Donbass subsample as the control group there is most likely to be similar in unobserved characteristics.

Regardless of the sample (the full or the censored one), coefficients of the DNR- and LNR-control are statistically significant at the 1\% level and are negative: -0.327 for DNR and -0.579 for LNR in a simple regression. Adding controls that account for violence intensity and the effect of the Minsk-II truce increases the effect: -0.480 for DNR and -0.706 for LNR. Since the regressions are of the loglevel form, the point estimates would imply a 30\% decline in the cell luminosity after introducing a DNR-regime and a 40\% decline for an LNR-regime (-38\% and $-51 \%$ respectively after adding controls). The differences in magnitudes of the DNR- and LNR-control are in line with the previous observations made by media (BBC, 2015a) and Mirimanova (2017), who pointed out that the LNR-controlled

\footnotetext{
${ }^{13}$ That is Kharkiv, Dnipropetrovsk, Zaporizhia, Donetsk, and Luhansk
} 
areas experienced a sharper economic downturn. Note that the effect of the truce agreement is significant for the DNR-controlled areas but not for LNR one - an increase of log luminosity by 0.265 or $30 \%$ for the Donbass sample.

As it follows from the estimations that do not account for additional controls, the magnitude of the coefficients declines with the average distance to the warafflicted areas. For instance, the point estimate for the DNR-control with the model that contains all regions of Ukraine (column All) is $-0.826(-1.077$ for LNRcontrol), while the estimated effect for the Donbass subsample is -0.327 ( -0.579 for LNR-control). The pattern remains the same irrespective to controlling for battle events, aggregation by quarters, restricting the sample to years 2013 - 2014 only or excluding the districts crossed by the contact line (see Tables 6, E.5, E.9).

This observation is important for the discussion on the direction of the bias caused by the spillover effects. If they would be at work, the decline in the magnitude of the point estimates would support the view that the negative spillovers are stronger than the positive ones. The assumption is that the regions close to the war-torn areas must be affected by the consequences of war greater than those unaffected directly by them (East Ukraine or Ukraine in general). Since the difference in the luminosity levels between the control and the treated group declines with the distance to the war-torn regions, the negative spillovers must be greater than the positive ones leading to an attenuation bias.

I test the robustness of the estimates in several ways. First, I exclude the cells that are located in the districts that contain a segment of the contact line that divides the separatist- and government-controlled areas. A concern is that local population and enterprises could strategically regulate the light illumination for security reasons (e.g. to permanently turn off lights to avoid artillery strikes or looters). As it follows from Table 6, reducing the sample size in the following manner does not alter the previous conclusions. The major change occurs in the relative magnitude between the coefficients for the DNR-, and LNR-control but the standard errors are too large to claim a marked difference between the two.

I additionally test the robustness by selecting the cells that lie within $20-40 \mathrm{~km}$ 
away from the contact line. The lower bound for the distance of the sample is mainly driven by the effective distance of the employed artillery to fire on target. ${ }^{14}$ The upper bound is selected to include enough observations that would include some government-controlled cities that were occupied by the separatist forces during at start of the conflict (April - June 2014).

Figures D.4, D.5 show the change of the average luminosity in the areas within the range for Donetsk and Luhansk regions. As one may notice, the pattern is similar to the one observed for the full sample of Donetsk and Luhansk regions. Table 6 confirms the impression. The values of the point estimates are similar to the ones obtained in Table 5 but with somewhat lower standard errors.

To evaluate whether the obtained point estimates for DNR- and LNR-control could be driven by expectations, I estimate regressions with a placebo treatment: a dummy variable that turns 1 for the separatist-controlled regions before the war started and is 0 otherwise (Bertrand, Duflo and Mullainathan, 2004). I introduce the placebo treatment in December 2013, when the massive protests against Yanukovich became permanent. I select the event as a placebo due to the high media coverage and a presumable impact on the protests in Donbass later on. To avoid multicollinearity between the placebo and the 'true treatment' variable, I restrict my sample to years 2013-2014 only.

Table E.6 shows that the estimations for the placebo treatment alone and with the 'true treatment'. In the first panel, the coefficient of DNR-control is insignificant at 5\% level, while the contrary is true for the LNR-control one. Yet the point estimates for it are at least two times smaller than the point estimates in Table E.5 and the coefficients are no more significant when both placebo and 'true treatment' are present in the regression. Notice also that the 'treatment' regressors stay virtually unaffected for the main control group (Donbass) and specifications with the region-specific time shocks.

\footnotetext{
${ }^{14} 2 \mathrm{~S} 19$ "Msta-S"- a $152.4 \mathrm{~mm}$ self-propelled howitzer used by both government and separatists armed forces - has a maximal range of fire within of $25 \mathrm{~km}$. Albeit according to the Minsk-II agreement, all artillery systems of caliber $100 \mathrm{~mm}$ and more must stay ca. $25 \mathrm{~km}$ away from the contact line, the media continuously reported about violations of the rule. Yet, it is unlikely that artillery of the type would be used within the distance of $5 \mathrm{~km}$ around the contact line, as it comes within the firing range of the portable infantry mortars.
} 
Tables E.5, E.7, E.10 in Appendix E show additional regression results with other specifications that include standard errors clustered at the regional level, estimations for years 2013-2014 only, and estimations for quarterly luminosity. The results discussed above remain robust to the changes for all of them.

\subsection{Impact of Trade}

The estimates of the previous subsection showed the effect of the separatist control on the nighttime luminosity. The results, however, show the aggregated effect and do not provide much information about the relative importance of different the channels that had an impact on the Donbass economy. I now exploit the trade ban - imposed by the government of Ukraine on the separatist-controlled areas - to identify the impact of the break-up of trade between the separatist and government-controlled areas.

In February 2017, the DNR- and LNR-governments introduced an 'external administration' at 46 enterprises that did not work in the 'legal space' of the separatists, continued to export goods to the third countries, and paid taxes to the government of Ukraine. The decision was formally caused by the actions of the pro-Ukrainian activists, who blocked the railroads connecting the separatist and government-controlled areas starting from January 25th, 2017. According to the DNR-messages, the 'external administration' was introduced as a temporary measure until the government of Ukraine unblocks the railway routes. Albeit Ukraine's government claimed to free the tracks by the beginning of March, the 'external administration' remained in force. As a result, Ukraine's government prohibited trade with the enterprises leading to a complete trade ban with the separatist economies.

The event could cause a negative impact on luminosity for the following reason. Most of the enterprises were major regional industrial plants (steel, coke, chemical production plants), coal mines and energy firms that had strategic importance for the region and local employment. As the trade ban effectively cut off the enterprises from their major market - Ukraine - it should negatively affect 
local real wages and reduce consumption. Assuming that the households residing closer to the enterprises are more likely to be employed there, the luminosity should fell down stronger in the areas close to the affected enterprises.

To identify a possible effect of the 'external administration' and the trade ban on the separatist economies I compare changes in luminosity in the urban areas that were most likely to be affected by the 'policy' with the all other urban areas within the territory of DNR. I restrict the sample to DNR only because only 3 of the nationalized enterprises were in LNR imposing a severe limit on the sample size. I proceed in the following way: I georeferenced the locations of the nationalized enterprises in DNR listed by (Euromaidanpress.com, 2017b). After manually georeferencing the locations of the enterprises using online search machines (see Table C.1 for detailed information), I assigned the treatment status to the cells that are located within a circle radius of $3.5 \mathrm{~km}$ away from any of the enterprise (see Figure6).

The area of the circle radius was selected to be approximately equal to a single city district of Donetsk (38.5 sq.km) that had around 100 thou. inhabitants per districts prior to the war. The control group for them consists of the cells that lie beyond the distance. To assure comparability and minimize the impact of expectations, I compare the luminosity levels for the cells from January 2016 to February 2018 with February 2017 as a date when the trade ban was implemented 15

A valid concern with respect to the identification strategy is related to the expectation of companies' management. The separatist leaders had a clear incentive to establish effective control over the major enterprises to collect taxes from the most valuable business assets Golunov and Artemev (2015). The management of the enterprises could, therefore, anticipate the events to come sooner or later and adapt their business strategies that would result in lower economic performance (for instance by cutting capital expenditures). Figure 7 demonstrates, however,

\footnotetext{
${ }^{15}$ I assume that all agents realized that separatist rule is going last long (and, therefore, formed their long-term expectations) by January 2016. First because as aggregated luminosity started to recover starting from the year (see Figures 4. 5). The recovery is also reflected in the business surveys of small and medium enterprises by Mirimanova (2017). Second, because neither side was able to advance its territorial control since March 2015.
} 
that the negative expectations did not take place as the luminosity of the presumably non-affected and affected areas do go in parallel prior to the treatment.

To test the robustness of the estimates, I provide the analysis for the subsamples selected exactly the same way shown in the previous subsection. Namely, I exclude cells within the districts that contain a segment of a contact line or select only the cells within the $20-40 \mathrm{~km}$ distance from the contact line. Unfortunately, the battle dataset by Zhukov, Davenport and Kostyuk (2017) does not extend beyond March 2016. Thus all estimates do not account for battle events that could happen. To mitigate the issue, I provide estimations that control for the districtspecific time shocks as a way to control for battle events at the district level. As Figures D.6, D.7 suggest, however, the sample selection is probably not balanced good enough as luminosity in the 'treatment' regions was growing faster than in the unaffected regions prior to the trade ban. I thus refer to the sample that contains all regions (column $\mathrm{All}$ ) as the benchmark one.

Table 8 shows the range of the point estimates of introducing the trade ban for the different subsamples. The regressor of interest is statistically significant at the $5 \%$ level among five out of six specifications with the only model, at which

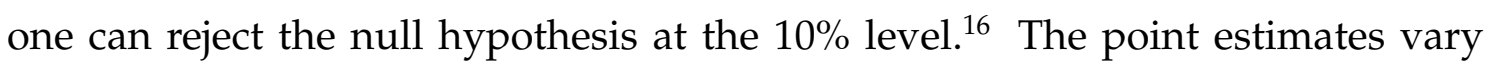
considerably once the district-specific time-shocks are introduced: from -0.196 to -0.337 in the baseline model and -0.096 to -0.227 after controlling for district-level trends. Yet as the limited samples reduce the number of 'treated' cells $\left(N_{A L L}=\right.$ $\left.643, N_{N C L}=151, N_{20-40}=74\right)$, I assume that the model with the district-specific time shocks (-0.227 implying $-21 \%$ decline) is more accurate.

Tables E.11, E.12, E.13 show that the results remain robust to placebo test (the placebo is set in October 2016 such that the length of the placebo treatment is twice as long as the 'true' one). Although the coefficients for the placebo treatment is statistically significant in a few specifications, the magnitude of the effect is smaller than for the 'true' treatment. Moreover, the statistical significance for the placebo-effect disappears as long as both the true and placebo treatments are

\footnotetext{
${ }^{16}$ One has to keep in mind, however, that the subsample contains only 74 unique 'treated' observations and a lot of additional controls are introduced due to district-specific time-shocks drastically reducing the degrees of freedom.
} 
estimated jointly.

\section{Discussion}

The estimates in the previous sections identified an aggregate impact of the separatist control (-38\% to $-50 \%$ in the benchmark model with controls) and an impact of the trade disruption coupled by a de-facto nationalization of assets (-20.3\%). Since we cannot be sure whether the effects are driven by the nationalization, most likely it was the trade ban that accounted for a fall in economic activity in the second case. Thus if the early stages of war appeared to be as prohibitive to trade as the trade ban introduced later, then half of the observed negative effect in Tables 5, E.5 could be attributed to the trade disruption only. Are there any reasons to believe it is indeed the case?

There are several of them. First, consider the differences in the point estimates between the DNR- and LNR-control and the respective effect of the truce implementation presented in Table 5. The point estimate for the impact of the truce in case of the DNR-controlled regions is 0.265 , which is very close to the magnitude of the trade disruption induced by the trade ban in February 2017. Note also that the differences in point estimates between the DNR- and the LNRcontrol in the baseline estimates is equal to 0.226 . This difference is also likely to be drawn by the severity of the trade disruption. According to surveys of small and medium enterprises in both state- and separatist-controlled areas $(\mathrm{N}=100)$ by Mirimanova (2017), Luhansk enterprises experienced a stronger break-up of trade relationships in the very beginning. By 2016, only 15\% of the SME in LNR confirmed they keep the supply chains with the Ukrainian partners directly or via third parties. This is 30\% less than the value reported by the DNR entrepreneurs. Donetsk region also has twice as many corridors (four versus two) that allow to migrate people and move goods across the contact line.

Some limited evidence comes from the pre-war external trade statistics coupled with some pencil and paper calculations. According to pre-war statistics of 2013, Donetsk region had a positive trade balance of 68 billion USD with a pre- 
war GDP of 171 billion USD (Osaulenka, 2014) implying the ratio of trade balance to GDP equal to $40 \%$. Assuming that a trade ban would drive export to the level of import ${ }^{17}$, the obtained estimates of a $20 \%$ impact easily fit in the range. Another piece of evidence from the dynamics of coal production - the major mining good in the region (see Table 9).

Production of the anthracite types of coal by DTEK - the largest coal mining and energy company of Ukraine that controlled two-thirds of the coal production in Donbass - dropped by 9.7 Mio tons from 2013 to 2015. Albeit the total regional production of the anthracite is unknown since 2015, it was most likely equal to the amount produced by DTEK because the company remained one of the few coal producers, which were able to sell coal to the 'mainland' Ukraine after the war started ${ }^{18}$ As of July 2017, the DTEK management estimated that separatists transported 0.2 Mio tons of coal per month to Russian Federation implying 2.4 Mio tons annually. If the estimation is right, the trade ban resulted in a drop of the anthracite production by 7.2 Mio tons. The decline of the coal production after the trade ban is, therefore, $74 \%$ of the production decline in the first two wartime years indirectly supporting the claim that the trade costs could account for half of the impact in the overall decline in economic activity at the early stages of the conflict.

The last piece of evidence comes from the company reports. A senior manager of the DTEK Group stated in August that the firm cannot transport coal. Partly due to security concerns, partly due to destroyed transport capacities:

Trolleys - the overhead power lines of the trains - are broken. The railway lines and infrastructure at the railway knots are destroyed. Employees do not go to the job due to hostilities. Moreover, there are many armed groups, which do not have a central authority. [...] Even if some DNR body gives us permission to move the goods, there is no

\footnotetext{
${ }^{17}$ Ukraine introduced a ban on export of goods from DNR and LNR unless enterprises reregister in the government-controlled areas.

${ }^{18}$ According to Ukraine's minister of energy and coal, the total demand for anthracite of Ukraine in 2016 was 9.5 Mio tons (Epravda.com.ua. 2017). The amount is very close to the volume produced by DTEK in 2016 suggesting that DTEK indeed was the only 'official' anthracite producer in Donbass since 2016.
} 
guarantee that another group will not stop it elsewhere. (Bystritckaia (2014))

Note that it was the inability to transport goods, not a depletion of capital stock at the mining sites that made the enterprise idle.

Conversely, the company reported a year later how the restoration of the railway connection helped to drastically increase the coal supply from the separatistcontrolled areas:

In August, DTEK helped to restore Nikitovka-Mayorska railway passage that was destroyed during military operations in 2014. These efforts allowed increased production and supply of coal from DTEK Sverdlovanthracite, DTEK Rovenkyanthracite, and DTEK Mine Komsomolets Donbassa mines. In July-December 2015, TPPs [thermal power plants - A.K.] of DTEK Energo received 2 million tonnes of anthracite coal from these mining companies, which is $160 \%$ or 1.4 million tonnes more year-on-year. In aggregate, the Company's TPPs received 3.2 million tonnes of coal from the ATO zone. (DTEK (2016))

The largest metal produced of Ukraine - the Metinvest holding - emphasized in the 2014 report that "none [italics mine - A.K.] of our iron ore production assets were damaged by the conflict" (Metinvest, 2015). Nonetheless, the railway destruction impeded the supply of goods from the ores to the production plants:

Beginning in late spring 2014, amid the conflict in Eastern Ukraine, key railway supply routes to our production assets were damaged or destroyed, while other facilities were disabled due to damage to electricity lines and substations. The subsequent logistical bottlenecks led to a significant drop in our production of coal, coke and crude steel. The Donetsk railway suffered more than 200 incidents of significant damage and lost up to $80 \%$ of its throughput capacity. (Metinvest (2015)) 
The inability to supply raw materials had a drastic effect on the production plants and overstocking of the produced goods:

In August-December 2014, the two plants received around 30\% of their raw materials from the port and shipped more than $60 \%$ of their steel products via it. [...]

Shipments of products from Krasnodon Coal were sharply restricted, leading to overstocking of the mine's warehouses. (Metinvest (2015))

Albeit the cases might look as suggestive evidence only, one has to keep in mind that DTEK and Metinvest controlled 70\% of Ukraine's coal production and $30 \%$ of steel production prior to conflict respectively. And in both cases, the damage to the energy and transport infrastructure appears to be at least as important as the effect of insecurity and damage to the capital. The reports also suggest that the slow luminosity recovery from mid-2015 shown by Figures 4 . 5 coincided with the restoration activities and finding the alternative supply routes.

It thus seems likely that the trade disruptions accounted roughly for half of the aggregated negative impact on the economy. In the next sections, I exploit the introduction of other policies that can help to identify the other channels that affected the wartime economies.

\subsection{Withdrawal of Banking and Public Services}

Starting from December 2014, Ukraine's authorities imposed a ban on banking operations, prohibited the social security payments and withdrew public services on the separatist-controlled areas (Walker, 2014). If implemented strictly, the measure would decrease local income levels and impose severe restrictions on the business operations and credit supply. I test the effect of the measures by introducing additional interaction dummy terms DNR-restrictions and LNRrestrictions to the equation 1 , which are equal 1 after November 2014 if the area is under separatist control and 0 otherwise. I also limit the sample to the period of January 2013 to March 2015 for several reasons: a) to avoid collinearity between 
the interaction terms, b) to exclude the possible support from Russia, which apparently started to subsidize local state budgets from the end of March (Golunov and Artemev, 2015).

I estimate the regression using the observations from January 2013 to March 2015. Table 10 shows, however, that if anything, there must have been a positive effect of the measures. There are several potential explanations of the findings. First, there is some evidence that the population of Donbass experienced serious problems with the access to banking and public services starting from July 2014 (UNICEF, 2014). Thus the restrictions imposed by the government could have little effect as the services were not effectively available since the start of the conflict. Additionally, a large chunk of the treatment period coincides with signing the effect of the truce signed on February 12th, 2015.

Agents could also adopt strategies to mitigate the impact of the restrictions. On the demand side, consumers most likely used their savings to compensate for the falling income flow or register in the government-controlled areas and get social security payments despite spending most of the time in the separatistcontrolled areas. $1^{19}$ On the supply side, firms could adopt strategies to bypass the imposed restrictions. Mirimanova (2017) and journalists (Golunov and Artemev, 2015), (Golovatjuk, 2017) mentioned the following ones: a) registering enterprises both in separatist and government areas, b) reselling their goods through thirdparty companies in Russia or South Ossetia, c) smuggling the goods across the contact line.

\subsection{Quality of Public Governance}

A second potential explanation is related to the quality of public governance. Local entrepreneurs complained about the changes in the tax system and the introduction of internal trade tariffs (Skorik, 2017). Enterprises, whose owners refused to re-register enterprises in the separatist republics were either nationalized starting from Spring 2015 or the executive managers got threats. Golunov and Arte-

\begin{tabular}{l}
\hline \hline${ }^{19}$ OSCE reported that 700 thou. people crossed the contact line every month in 2016 (OSCE.org, \\
N.d.).
\end{tabular}


mev (2015) reported that armed people kept the CEO of the "Donetskkoks" plant in a trunk of a car for several days demanding to re-register the enterprise in DNR.

To see whether one can find support for the effects, I compare the baseline estimates of the impact of the separatist control for the whole sample (Table 5) and for the years 2013 and 2014 only (Table E.5). As one may see, the magnitude of the point estimates fell over time. Within the Donbass region, the point estimate for the DNR-control was equal to -0.455 (-0.515 for LNR) for years 2013-2014 versus -0.365 (-0.421 for LNR) for years 2013-2016 (both estimates control for battle events). The analysis is, however, undermined by fact that the changes coincided with the second truce signed in February 2015 that led to a temporary decline in the battle intensity.

\subsection{Perceived Security}

The last explanatory factor, frequently mentioned in the reports, is the change in perceived security. As discussed in the previous subsection, the negative impact of the separatist control on the economic activity was stronger in the first year of the armed conflict. This also coincided with a large number of internally displaced persons, most of which (98\%) came from the Donbass area. Albeit there are no sources that would contain information on the detailed (say district-level) migration flows, the aggregate numbers are available. Figure 8 shows the number of internally displaced persons (IDP) officially registered in Ukraine.

Although it does not account for refugees that fled to the neighboring countries, it is reasonable to assume that it provides a fair approximation of the dynamics of the total emigration from both separatist areas. Figure 8 makes clear that the largest growth of the IDPs happened between June and December 2014. Note that there is no strong correlation between the battle intensity and the number of the internally displaced people. The monthly flow was close to 100000 per month until December with the largest jump occurring between November and December 2014, when the conflict intensity passed its peak and stayed stable for 
three months.

There is survey evidence that indirectly supports the hypothesis. In June 2014, UNICEF (2014) found that around half of the surveyed people $(N=435)$ residing in urban areas of Donbass confirmed that people in their districts made the plans to leave. They also found the number of districts with a high perception of insecurity was greater than the number of the districts where the hostilities were taking place.

One can also find supporting evidence at the "grassroots" level. The Donetsk journalist Stanislav Vasin - one of the few ones that worked for the Ukrainian media from inside of the separatist republics - described the emigration groups from Donetsk as a two-wave process. According to him, the first (and the largest one) was driven by emotional stress caused by the insecurity:

Some people, who had families with little children and were woken up by the strikes of the rocket assault launcher in the yard, said it is not Ukraine anymore. And it's not even the war that mattered. For the people, the war became a consequence of the euphoria of the neighbors', who truly believed that rocket launchers are needed because there is a "Ukrainian nazi" standing just a few kilometers away from there. The fact that the rockets were launched from a children playground did not surprise anyone. The absurd became a catalyst for the first emigrant wave, who left "DNR" and moved to the "mainland". (Vasin (2016))

The second wave left the territories after realizing the separatist rule is going to stay for a long time:

After a modest recovery from a shock in 2014 [...] the second ones came. Those, who after living in an occupation for a year, decided that the war is going to stay forever. And it does not matter when it all ends because chances are it is not going to happen within the next 2-5 years. But even after that, one will have to spend years to rebuild 
everything that was destroyed, including people's minds themselves.

This job is for the next generations. But those who lived in "DNR" at least a year do not have extra time anymore. (Vasin (2016))

Albeit one cannot find a more grounded quantitative support for the impact of perceived security, it is the only discussed determinant that does not contradict results presented in the paper.

\section{Conclusion}

The data on the nighttime lights in Ukraine allow reaching several conclusions about the state of the separatist economies. First, the separatist-controlled areas experienced a stronger economic downturn compared to government-controlled ones: $-38 \%$ for Donetsk region and $-51 \%$ for Luhansk region. The difference in the magnitudes between the two separatist areas appears to be in line with the assessments suggested by media although the overall magnitude of the satellitebased estimations is lower than -50\%-80\% reported by BBC (2015a) in May 2015.

Second, the trade disruptions caused by conflict or introduced by the economic sanctions appear to play a significant role in the observed economic downturn. The second round of the trade ban against the DNR enterprises resulted in a $-20 \%$ decline in the local economic activity. Although one cannot identify the impact of the trade distortions caused by the war actions during the early stage of the conflict directly, the indirect assessments based on the post-truce recovery, difference in the point estimates between Luhansk and Donetsk regions, and the pre-war trade statistics suggest that the trade disruption accounted for roughly half of the magnitude attributed to the negative effect of the separatist-rule.

This observation has an implication for the discussion about the effectiveness of the economic sanctions, which frequently go hand-in-hand with the military action against an enemy state. Despite the wide use of economic sanctions in international politics, the record of cases when sanctions achieved their goal is poor (Pape, 1997). Furthermore, the cases of North Korea (Lee, 2018) and Palestina 
(Calì and Miaari, 2015) show that they may even backfire and produce an opposite result.

It looks like that the case of Ukraine is not going to improve the success record of economic sanctions in its current state. The sanctions primarily target the whole population and hit hardest those ones, who had the deepest trade connections with the "rest of Ukraine" prior to the war. At the same time, the mass turnout at the funeral of Alexandr Zakharchenko - the former prime-minister of DNR assassinated in August 2018 - indicates that the separatist elites still enjoy the public support. If this interpretation is right, the economic sanctions against the separatist-controlled areas achieve little more than suppressing the local economic activity, promoting smuggling and corruption across the contact line, and dividing the opposing sides even more. 


\section{References}

Abadie, Alberto and Javier Gardeazabal. 2003. "The economic costs of conflict:

A case study of the Basque Country." The American Economic Review 93(1):113132.

Amodio, Francesco, Leonardo Baccini and Michele Di Maio. 2017. “Security, Trade, and Political Violence." Working Paper.

Barbelet, Veronique. 2017. "Humanitarian access and local organisations in Ukraine." Working paper.

BBC. 2014a. "Ukraine crisis: timeline.". https://archive.is/M5RU7, bbc.com, [Online; posted 13-11-2014].

BBC. 2014b. "Ukraine unrest: Protesters storm regional offices.". https: // archive.is/zXtVL, bbc.com, [Online; posted 24-01-2014].

BBC. 2015a. "God posle "referendumov" DNR/LNR: poteri ekonomiki.". https: //goo.gl/kZ4mTK, bbc.com, [Online; posted 12-05-2017].

BBC. 2015b. “Ukraine ceasefire: New Minsk agreement key points.”. https: / / archive.is/m7PFO, bbc.com, [Online; posted 12-02-2015].

Bertrand, Marianne, Esther Duflo and Sendhil Mullainathan. 2004. "How much should we trust differences-in-differences estimates?" The Quarterly Journal of Economics 119(1):249-275.

Besley, Timothy and Hannes Mueller. 2012. “Estimating the Peace Dividend: The impact of violence on house prices in Northern Ireland." The American Economic Review 102(2):810-33.

Blattman, Christopher and Edward Miguel. 2010. "Civil war." Journal of Economic Literature 48(1):3-57.

Brauer, Jurgen and Paul Dunne. 2012. Peace economics: a macroeconomic primer for violence-afflicted states. United States Institute of Peace Academy guides. 
Bystritckaia, Olga. 2014. "Razrushennyi Donbass: kto i skolko poterial izza voiny v regione.". https://archive.is/dF26E, cfts.org.ua, [Online; posted 26-08-2014].

Calì, Massimiliano and Sami H Miaari. 2015. Should I trade or should I go (to war)? Lessons from the Second Intifada. Technical report Hicn working paper 186.

Chen, Xi and William Nordhaus. 2015. "A test of the new VIIRS lights data set: Population and economic output in Africa." Remote Sensing 7(4):4937-4947.

Chernenko, Elena. 2018. "Interview of the deputy director of the special monitoring mission of OSCE in Ukraine.". https : / / archive.is / QRu 0 j, kommerstant.ru, [Online; posted 19-06-2018].

Collier, Paul, V. L. Elliott, Håvard Hegre, Anke Hoeffler, Marta Reynal-Querol and Nicholas Sambanis. 2003. Breaking the conflict trap: Civil war and development policy. World Bank Publications.

Coupé, Tom and Maksym Obrizan. 2016. "Violence and political outcomes in Ukraine-Evidence from Sloviansk and Kramatorsk." Journal of Comparative Economics 44(1):201-212.

Coupe, Tom, Michał Myck and Mateusz Najsztub. 2016. “And the Lights Went Out - Measuring the Economic Situation in Eastern Ukraine.". g00.gl/ xKC8C7, VoxUkraine.org, [Online; posted 18-July-2016].

D’Agata, Charlie. 2014. “Ukrainian city of Donetsk epitomizes country's crisis.”. https://archive.is/KABs5, cbsnews.com, [Online; posted 01-03-2014].

De Bono, Andrea and Bruno Chatenoux. 2015. "A global exposure model for GAR 2015." UNEP-GRID, GAR . https://data.humdata.org/dataset/ gar15-global-exposure-dataset-for-ukraine, humdata.org, [Online]. 
DTEK. 2015. “Integrated Report 2014.". https : / / goo.gl/GS2GT2, dtek.com, [Online].

DTEK. 2016. “Integrated Report 2015.". https : / /goo.gl/byo2kc, dtek.com, [Online].

DTEK. 2017a. “Integrated Report 2016.". https : / / goo.gl/QWknHb, dtek.com, [Online].

DTEK. 2017b. “Rukovoditel' Antikrizisnogo shtaba DTJeK Denis Didenko o tom, v kakom sostojanii segodnja predprijatija na NKT, kuda edet ugol', i kto ego prodaet.". https://archive.is/kwCQI, dtek.com, [Online; posted 24-072017].

Dube, Arindrajit, T William Lester and Michael Reich. 2010. "Minimum wage effects across state borders: Estimates using contiguous counties." The Review of Economics and Statistics 92(4):945-964.

Elvidge, Christopher D, Kimberly E Baugh, Mikhail Zhizhin and Feng-Chi Hsu. 2013. "Why VIIRS data are superior to DMSP for mapping nighttime lights." Proceedings of the Asia-Pacific Advanced Network 35:62-69.

Epravda.com.ua. 2017. "Dobycha uglia v Ukraine upala na 27\%.". https:// archive.is/JxquY, eplavda.com.ua, [Online; posted 22-07-2017].

Euromaidanpress.com. 2017. “Ukraine imposes official blockade on occupied territories demanding stolen assets back.". https: / / archive.is/rS9FR, euromaidanpress.com, [Online; posted 16-03-2017].

Euromaidanpress.com. 2017a. “What assets did Russia's puppet republics seize from Ukraine? Full list.". https://archive.is/HmPzx, euromaidanpress.com, [Online; posted 04-03-2017].

Euromaidanpress.com. 2017b. "Will the makeshift blockade in Donbas hit the Russian-backed enclaves' economy?". https: / / archive.is/P0QJr, euromaidanpress.com, [Online; posted 09-02-2017]. 
Fadeeva, Alina and Dmitrii Serkov. 2018. "Sekrety Donbassa: v chem FSB podozrevaet Karinu Tcurkan.". https://archive.is/OCLxk, rbc.ru, [Online; posted 25-06-2018].

Garfinkel, Michelle R and Stergios Skaperdas. 2012. The Oxford Handbook of the Economics of Peace and Conflict. OUP USA.

Golovatjuk, Evgenij. 2017. “Denezhnyi Grad. Ekonomika okkupirovannogo Donbassa: igroki, skhemy, obemy.". https://goo.gl/HsvAVn, Liga.net, [Online; posted 11-08-2017].

Golunov, Ivan and Aleksandr Artemev. 2015. “Rassledovanie RBK: na chi dengi zhivet Donbass.". https : / / archive.is/y8cYT, Rbc.ru, [Online; posted 0106-2015].

Gorchinskaya, Katya. 2013. “EuroMaidan rallies in Ukraine - Dec.9.”. https : // archive.is/tFKCT, kyivpost.com, [Online; posted 09-12-2013].

Gorodnichenko, Yuriy and Oleksandr Talavera. 2016. “How's DNR Economy Doing.". https://goo.gl/Zfmc3X, VoxUkraine.org, [Online; posted 7-April2016].

Havlik, Peter and Vasily Astrov. 2014. “Economic consequences of the Ukraine conflict." wiiw Policy Notes and Reports (14).

Henderson, J Vernon, Adam Storeygard and David N Weil. 2012. “Measuring economic growth from outer space." The American Economic Review 102(2):9941028.

Hijmans, Robert, Nell Garcia and John Wieczorek. 2015. “Global Administrative Areas Project (GADM).". https: / / gadm. org, Gadm.org, [Online].

Kirillov, Dmitrii. 2017. “Donbass mozhno vernut tolko diplomatiei.". https: //archive.is/tUWK3, Gazeta.ru, [Online; posted 19-01-2017].

Kremlin.ru. 2017. “Ukaz o priznanii dokumentov, vydannyh grazhdanam Ukrainy i licam bez grazhdanstva, prozhivajushhim na territorijah otdel'nyh 
rajonov Doneckoj i Luganskoj oblastej Ukrainy.". https://archive.is/ EtLKW, kremlin.ru, [Online; posted 17-02-2017].

Ksoll, Christopher, Rocco Macchiavello and Ameet Morjaria. 2009. "Guns and Roses: The Impact of the Kenyan Post-Election Violence on Flower Exporting Firms." Working Paper .

Kuznetsov, Andriy. 2014. "Luhansk Dispatch: Armed Pro-Russian Protesters Set For Standoff With Police.". https : / / archive. is / U5FZh, rferl.org, [Online; posted 07-04-2014].

Kyivpost.com. 2013a. "Backstage at EuroMaidan as 100,000 people watch.". https: / / archive.is/9yslm, kyivpost.com, [Online; posted 24-11-2013].

Kyivpost.com. 2013b. "EuroMaidan rallies in Ukraine - Nov. 29 coverage.". https: / / archive.is/DSAwU, kyivpost.com, [Online; posted 01-12-2013].

Lee, Yong Suk. 2018. "International isolation and regional inequality: Evidence from sanctions on North Korea." Journal of Urban Economics 103:34-51.

Li, Xi and Deren Li. 2014. "Can night-time light images play a role in evaluating the Syrian Crisis?" International Journal of Remote Sensing 35(18):6648-6661.

Li, Xi, Deren Li, Huimin Xu and Chuanqing Wu. 2017. “Intercalibration between DMSP/OLS and VIIRS night-time light images to evaluate city light dynamics of Syria's major human settlement during Syrian Civil War." International Journal of Remote Sensing 38(21):5934-5951.

Makarin, Alexey and Vasily Korovkin. 2018. "Trading with the Enemy: The Impact of Conflict on Trade Transactions in Non-Conflict Areas." Working paper

Martin, Philippe, Thierry Mayer and Mathias Thoenig. 2008. "Civil wars and international trade." Journal of the European Economic Association 6(2-3):541-550.

Mediarnbo.org. 2018. "Karta OOS.". https://archive.is/jxRAj, mediarnbo.org, [Online; posted 10-05-2018]. 
Metinvest. 2015. "Annual Report and Financial Statements 2014.". https:// goo.gl/esFGno, metinvestholding.com, [Online].

Mirimanova, Natalia. 2017. "Economic connectivity across the line of contact in Donbas, Ukraine." Working paper .

Mueller, Hannes. 2013. The Economic Cost of Conflict. Technical report International Growth Centre.

NOAA. 2018. “Version 1 VIIRS Day/Night Band Nighttime Lights.”. https : // WwW.ngdc.noaa.gov/eog/viirs/download_dnb_composites.html

[Monthly averaged, vcm Tile 2 images; months: October-March; years: 2013 2016].

OCHA. 2014. Ukraine: Situation Reports. Technical report United Nations Office for the Coordination of Humanitarian Affairs (OCHA).

Osaulenka, O., ed. 2014. Statistical publication: Regions of Ukraine. State Statistics Service of Ukraine.

OSCE. 2015. "Content of the Minsk II agreement.". https: / /www. osce.org/ ru/cio/140221 ?download=true, osce.org, [Online; posted 15-02-2015].

OSCE.org. N.d. "Daily and spot reports from the Special Monitoring Mission to Ukraine.". http://www.osce.org/\{U\}kraine-smm/reports, osce.org, [Online].

Pape, Robert A. 1997. "Why economic sanctions do not work." International security 22(2):90-136.

Pinkovskiy, Maxim. 2017. "Growth discontinuities at borders." Journal of Economic Growth 22(2):145-192.

Pinkovskiy, Maxim and Xavier Sala-i Martin. 2014. Lights, Camera,... Income!: Estimating Poverty Using National Accounts, Survey Means, and Lights. Technical report National Bureau of Economic Research. 
Pravda.com.ua. 2014. "V Donetcke sozdali partiiu "Novorossiia".". https:// archive.is/rnn3v, pravda.com.ua, [Online; posted 22-05-2014].

President.gov.ua. 2014. "Sostoialos podpisanie Soglasheniia ob uregulirovanii krizisa v Ukraine.". https: / / archive.is/t 5 cro, bbc.com, [Online; posted 24-01-2014].

Rachkevych, Mark. 2014. “Armed pro-Russian extremists launch coordinated attacks in Donetsk Oblast, seize regional police headquarters, set up checkpoints.". https://archive.is/fcYgo, kyivpost.com, [Online; posted 1204-2014].

Rada.gov.ua. 2014. “Postanova vid 16 grudnia 2015 r. No. 1035.". https:// archive.is/7is3f, Rada.gov.ua, [Online; posted 16-12-2014].

Ray, Debraj. 2010. “Uneven growth: A framework for research in development economics." Journal of Economic Perspectives 24(3):45-60.

RBK. 2014a. "Russkie zamorozki: Bystraia pobeda v Krymu obernulas dolgoi voinoi.". https : / / archive.is/Coimu, rbc.ru, [Online; posted 26-12-2014].

RBK. 2014b. "Strelkov vvel v Donetcke osadnoe polozhenie.". https:// archive.is/ADTai, rbc.ru, [Online; posted 31-07-2014].

RIA. 2018. "“'Oni ubivaiut detei i pensionerov". Zachem Ukraina snova atakuet Donbass.". https://archive.is/KqRnG, ria.ru, [Online; posted 25-052018].

Schneider, Annemarie, Mark A Friedl and David Potere. 2009. "A new map of global urban extent from MODIS satellite data." Environmental Research Letters 4(4):044003. https: / / archive.is/B5ZzS, fao.org, [Online].

Segonya.ua. 2014. "'DNR" i "LNR" oficial'no priznany terroristicheskimi organizacijami - GPU.". https://archive.is/hmJji, segonya.ua, [Online; posted 16-05-2014]. 
Shevchenko, Daryna. 2013. "Back to the Middle Ages on the way to Europe: Beaten Kyiv protesters take refuge in ancient church yard.". https: / / archive.is/N5LYM, kyivpost.com, [Online; posted 30-11-2013].

Skorik, Mikhail. 2017. “Kak dela delaiutsia. Na chem derzhatsia ekonomika i finansy DNR i LNR.". https://goo.gl/LLAuzf, Spektr.press, [Online; posted 08-02-2017].

Smith, Ron P. 2014. "The economic costs of military conflict." Journal of Peace Research 51(2):245-256.

Smith-Spark, Laura and Kellie Morgan. 2014. “Ukraine unrest will be resolved by force or talks in 48 hours, minister says.". https: / / archive. is / ICIjK, cnn.com, [Online; posted 10-04-2014].

UNIAN. 2014. “Terrorist Strelkov reshil vvesti v Donetcke voennoe polozhenie i komendantskii chas - SMI.". https: / / archive.is/ZxhD j, unian.net, [Online; posted 16-07-2014].

UNIAN. 2015. “Zmi opublikuvali tochnu mapu linii rozmezhuvannja sil na Donbasi.". https: / / archive.is/xYSa3, Unian.ua, [Online; posted 12-012015].

UNIAN. 2017. “Ukraine Army reports 1 WIA, 22 enemy attacks in Donbas in last day.". https: / / archive. is /ArNGA, unian.info, [Online; posted 28-112017].

UNICEF. 2014. Ukraine: Humanitarian Situation Monitoring, Phase 1 Report. Technical report UNICEF.

Vasin, Stanislav. 2016. "“Ostavshiesia": neizvestnyi Boskh v "DNR".". https: //goo.gl/c3wF7x, zn.ua, [Online; posted 09-07-2016].

Walker, Shaun. 2014. "Ukraine banks axe services in pro-Russian regions.". https://archive.is/bMgan, theguardian.com, [Online; posted 26-112014]. 
Witmer, Frank DW and John O'Loughlin. 2011. "Detecting the effects of wars in the Caucasus regions of Russia and Georgia using radiometrically normalized DMSP-OLS nighttime lights imagery." GIScience E Remote Sensing 48(4):478500.

Zavtra.ru. 2014. "Kto ty, «Strelok»?". https://archive.is/XxP50, kyivpost.com, [Online; posted 20-11-2014].

Zhukov, Yuri M. 2016. “Trading hard hats for combat helmets: The economics of rebellion in eastern Ukraine." Journal of Comparative Economics 44(1):1-15.

Zhukov, Yuri M, Christian Davenport and Nadiya Kostyuk. 2017. "Introducing xSub: A New Portal for Cross-National Data on Sub-National Violence.". http://cross-sub.org/, cross-sub.com, [Online]. 


\section{Appendix}

Description: Contains figures and tables intended to be included in the core text of the paper. 


\section{A Tables}

Table 1: Economic Characteristics of the $5 \times 5 \mathrm{~km}$ Urban Areas of Governmentand Separatist-controlled Areas in Donetsk Prior to the War

\begin{tabular}{lccccc}
\hline \multirow{2}{*}{ Variable } & \multicolumn{2}{c}{ Government $(N=112)$} & & \multicolumn{2}{c}{ Separatists $(N=128)$} \\
\cline { 2 - 3 } & Mean & Std. Dev. & & Mean & Std. Dev. \\
\hline Urban & 12047 & 23238 & & 19613 & 33920 \\
Rural & 5895 & 5440 & & 7389 & 5360 \\
Total & 17942 & 23690 & & 27001 & 33193 \\
& \multicolumn{3}{c}{ Population } \\
Total Stock, Mio USD & 117 & 157 & & & \\
Per capita, USD & 6357 & 308 & & 6430 & 251 \\
\hline
\end{tabular}

Source: GAR 15 Dataset by De Bono and Chatenoux (2015), Only cells within the urban areas from MODIS-dataset Schneider, Friedl and Potere (2009) selected.

Table 2: Economic Characteristics of the $5 \times 5 \mathrm{~km}$ Urban Areas of Governmentand Separatist-controlled Areas in Luhansk Region Prior to the War

\begin{tabular}{lccccc}
\hline \multirow{2}{*}{ Variable } & \multicolumn{2}{c}{ Government $(N=40)$} & & \multicolumn{2}{c}{ Separatists $(N=75)$} \\
\cline { 2 - 3 } \cline { 5 - 6 } & Mean & Std. Dev. & & Mean & Std. Dev. \\
\cline { 1 - 2 } Urban & 12093 & 20290 & & 16362 & 31011 \\
Rural & 4835 & 4187 & & 5485 & 4152 \\
Total & 16928 & 20705 & & 21847 & 30730 \\
& \multicolumn{3}{c}{ Copulation } \\
Total Stock, Mio USD & 92 & 113 & & 119 & 168 \\
Per capita, USD & 5397 & 249 & & 5449 & 225 \\
\hline
\end{tabular}

Source: GAR 15 Dataset by De Bono and Chatenoux (2015), Only cells within the urban areas from MODIS-dataset Schneider, Friedl and Potere (2009) selected. 
Table 3: Descriptive Statistics Before and At War, Donetsk Region

\begin{tabular}{|c|c|c|c|c|c|c|c|c|}
\hline & \multicolumn{4}{|c|}{ Before war: 01.2013 - 03.2014} & \multicolumn{4}{|c|}{ At war: $10.2014-03.2016$} \\
\hline & \multicolumn{2}{|c|}{ State } & \multicolumn{2}{|c|}{ DNR } & \multicolumn{2}{|c|}{ State } & \multicolumn{2}{|c|}{ DNR } \\
\hline & Mean & s.d. & Mean & s.d. & Mean & s.d. & Mean & s.d. \\
\hline Luminosity & 5.07 & 19.87 & 6.19 & 12.15 & 2.82 & 7.94 & 2.88 & 8.60 \\
\hline Log Luminosity & 0.65 & 1.29 & 0.99 & 1.34 & -0.04 & 1.67 & -0.06 & 1.66 \\
\hline Cell's area (sq. km) & 0.79 & 0.08 & 0.80 & 0.06 & 0.79 & 0.08 & 0.80 & 0.06 \\
\hline All violence & 0.24 & 1.04 & 0.80 & 3.91 & 22.45 & 17.29 & 24.23 & 19.50 \\
\hline Luminosity growth & -0.72 & 1.20 & -0.52 & 1.85 & -0.80 & 0.77 & -0.99 & 0.88 \\
\hline
\end{tabular}

Notes: Luminosity growth $g$ is calculated as follows $g=\ln \left(L u m_{t+1}\right)-\ln \left(L u m_{t}\right)$. Sources: luminosity tiles: NOAA (2018), regional borders: Hijmans, Garcia and Wieczorek (2015), urban areas: Schneider, Friedl and Potere (2009), contact line: based on UNIAN](2015), Mediarnbo.org (2018).

Table 4: Descriptive Statistics Before and At War, Luhansk Region

\begin{tabular}{|c|c|c|c|c|c|c|c|c|}
\hline & \multicolumn{4}{|c|}{ Before war: 01.2013 - 03.2014} & \multicolumn{4}{|c|}{ At war: $10.2014-03.2016$} \\
\hline & \multicolumn{2}{|c|}{ State } & \multicolumn{2}{|c|}{ LNR } & \multicolumn{2}{|c|}{ State } & \multicolumn{2}{|c|}{ LNR } \\
\hline & Mean & s.d. & Mean & s.d. & Mean & s.d. & Mean & s.d. \\
\hline Luminosity & 3.50 & 6.93 & 3.25 & 5.58 & 2.31 & 4.65 & 1.33 & 2.41 \\
\hline Log Luminosity & 0.36 & 1.30 & 0.42 & 1.21 & -0.43 & 2.42 & -0.88 & 2.58 \\
\hline Cell's area (sq. km) & 0.78 & 0.07 & 0.78 & 0.08 & 0.78 & 0.07 & 0.78 & 0.08 \\
\hline All violence & 0.11 & 0.36 & 0.34 & 1.88 & 17.58 & 14.02 & 18.97 & 15.22 \\
\hline Luminosity growth & -0.92 & 0.76 & -0.85 & 0.74 & -1.54 & 3.38 & -1.87 & 2.91 \\
\hline
\end{tabular}

Notes: Luminosity growth $g$ is calculated as follows $g=\ln \left(L u m_{t+1}\right)-\ln \left(L u m_{t}\right)$. Sources: luminosity tiles: NOAA (2018), regional borders: Hijmans, Garcia and Wieczorek (2015), urban areas: Schneider, Friedl and Potere (2009), contact line: based on UNIAN](2015), Mediarnbo.org (2018). 
Table 5: Impact of the Separatist-Control on Luminosity, Monthly Based

\begin{tabular}{|c|c|c|c|c|c|c|c|c|}
\hline & \multicolumn{4}{|c|}{ No Controls } & \multicolumn{4}{|c|}{ With Controls } \\
\hline & All & East Ukraine & Donbass & All (RSTS) & All & East Ukraine & Donbass & All (RSTS) \\
\hline DNR-control & $\begin{array}{c}-0.826^{* * *} \\
(0.081)\end{array}$ & $\begin{array}{c}-0.798^{* * *} \\
(0.089)\end{array}$ & $\begin{array}{c}-0.327^{* * *} \\
(0.100)\end{array}$ & $\begin{array}{c}-0.357^{* * *} \\
(0.105)\end{array}$ & $\begin{array}{c}-0.482^{* * *} \\
(0.096)\end{array}$ & $\begin{array}{c}-0.535^{* * *} \\
(0.100)\end{array}$ & $\begin{array}{c}-0.480^{* * *} \\
(0.114)\end{array}$ & $\begin{array}{c}-0.487^{* * *} \\
(0.129)\end{array}$ \\
\hline LNR-control & $\begin{array}{c}-1.077^{* * *} \\
(0.128)\end{array}$ & $\begin{array}{c}-1.049^{* * *} \\
(0.135)\end{array}$ & $\begin{array}{c}-0.579^{* * *} \\
(0.156)\end{array}$ & $\begin{array}{c}-0.506^{* *} \\
(0.209)\end{array}$ & $\begin{array}{c}-0.721^{* * *} \\
(0.142)\end{array}$ & $\begin{array}{c}-0.778^{* * *} \\
(0.141)\end{array}$ & $\begin{array}{c}-0.706^{* * *} \\
(0.148)\end{array}$ & $\begin{array}{c}-0.690^{* * *} \\
(0.159)\end{array}$ \\
\hline Crimea: Russia-control & $\begin{array}{l}-0.062 \\
(0.060)\end{array}$ & & & $\begin{array}{l}-0.546^{*} \\
(0.324)\end{array}$ & $\begin{array}{c}-0.149^{* * *} \\
(0.057)\end{array}$ & & & $\begin{array}{l}-0.276 \\
(0.194)\end{array}$ \\
\hline Minsk II Effect: DNR & & & & & $\begin{array}{l}0.112^{* *} \\
(0.052)\end{array}$ & $\begin{array}{c}0.180^{* * *} \\
(0.058)\end{array}$ & $\begin{array}{c}0.265^{* * *} \\
(0.075)\end{array}$ & $\begin{array}{c}0.210^{* * *} \\
(0.070)\end{array}$ \\
\hline Minsk II Effect: LNR & & & & & $\begin{array}{c}0.009 \\
(0.094)\end{array}$ & $\begin{array}{c}0.077 \\
(0.097)\end{array}$ & $\begin{array}{c}0.162 \\
(0.103)\end{array}$ & $\begin{array}{l}0.291^{*} \\
(0.156)\end{array}$ \\
\hline All violence & & & & & $\begin{array}{c}-0.185^{* * *} \\
(0.032)\end{array}$ & $\begin{array}{c}-0.199^{* * *} \\
(0.034)\end{array}$ & $\begin{array}{c}-0.130^{* * *} \\
(0.044)\end{array}$ & $\begin{array}{c}-0.144^{* * *} \\
(0.043)\end{array}$ \\
\hline Observations & 351309 & 216489 & 112518 & 351309 & 351309 & 216489 & 112518 & 351309 \\
\hline Adjusted $R^{2}$ & 0.176 & 0.227 & 0.298 & 0.257 & 0.187 & 0.244 & 0.303 & 0.260 \\
\hline
\end{tabular}

Notes: ${ }^{*} p<0.10,{ }^{* *} p<0.05,{ }^{* * *} p<0.01$, standard errors in parentheses, clustered by districts. Dependent variable: logarithm of a mean monthly luminosity. Time covered: January 2013 - March 2016. Standard errors clustered by districts. All models include individual and time fixed effects. Columns All contain all regions; East Ukraine: Dnipropertovks, Kharkiv, Zaporizhia, Donetsk, Luhansk; Donbass: Donetsk, Luhansk. Columns All (RSTS) include region-specific time shocks. Sources: nighttime luminosity tiles by NOAA (2018), district borders by Hijmans, Garcia and Wieczorek (2015), urban areas by Schneider, Friedl and Potere (2009), the contact line based on UNIAN (2015) and Mediarnbo.org (2018). 
Table 6: Impact of the Separatist-Control on Luminosity, No Districts at the Contact Line, Monthly Based

\begin{tabular}{|c|c|c|c|c|c|c|c|c|}
\hline & \multicolumn{4}{|c|}{ No Controls } & \multicolumn{4}{|c|}{ With Controls } \\
\hline & All & East Ukraine & Donbass & All (RSTS) & All & East Ukraine & Donbass & All (RSTS) \\
\hline DNR-control & $\begin{array}{c}-0.753^{* * *} \\
(0.073)\end{array}$ & $\begin{array}{c}-0.784^{* * *} \\
(0.080)\end{array}$ & $\begin{array}{c}-0.434^{* * *} \\
(0.084)\end{array}$ & $\begin{array}{c}-0.487^{* * *} \\
(0.072)\end{array}$ & $\begin{array}{c}-0.632^{* * *} \\
(0.092)\end{array}$ & $\begin{array}{c}-0.697^{* * *} \\
(0.095)\end{array}$ & $\begin{array}{c}-0.629^{* * *} \\
(0.093)\end{array}$ & $\begin{array}{c}-0.668^{* * *} \\
(0.089)\end{array}$ \\
\hline LNR-control & $\begin{array}{c}-0.717^{* * *} \\
(0.111)\end{array}$ & $\begin{array}{c}-0.748^{* * *} \\
(0.116)\end{array}$ & $\begin{array}{c}-0.398^{* * *} \\
(0.120)\end{array}$ & $\begin{array}{c}-0.298^{*} \\
(0.157)\end{array}$ & $\begin{array}{c}-0.507^{* * *} \\
(0.148)\end{array}$ & $\begin{array}{c}-0.574^{* * *} \\
(0.149)\end{array}$ & $\begin{array}{c}-0.497^{* * *} \\
(0.149)\end{array}$ & $\begin{array}{c}-0.425^{* *} \\
(0.165)\end{array}$ \\
\hline Crimea: Russia-control & $\begin{array}{c}-0.121^{* *} \\
(0.057)\end{array}$ & & & $\begin{array}{l}0.360^{* *} \\
(0.179)\end{array}$ & $\begin{array}{c}-0.146^{* *} \\
(0.057)\end{array}$ & & & $\begin{array}{c}0.320 \\
(0.200)\end{array}$ \\
\hline Minsk II Effect: DNR & & & & & $\begin{array}{c}0.153^{* * *} \\
(0.052)\end{array}$ & $\begin{array}{c}0.218^{* * *} \\
(0.057)\end{array}$ & $\begin{array}{c}0.319^{* * *} \\
(0.067)\end{array}$ & $\begin{array}{c}0.288^{* * *} \\
(0.059)\end{array}$ \\
\hline Minsk II Effect: LNR & & & & & $\begin{array}{c}-0.003 \\
(0.082)\end{array}$ & $\begin{array}{c}0.064 \\
(0.087)\end{array}$ & $\begin{array}{l}0.153^{*} \\
(0.083)\end{array}$ & $\begin{array}{c}0.210 \\
(0.127)\end{array}$ \\
\hline All violence & & & & & $\begin{array}{c}-0.122^{* * *} \\
(0.022)\end{array}$ & $\begin{array}{c}-0.141^{* * *} \\
(0.024)\end{array}$ & $\begin{array}{c}-0.054^{* *} \\
(0.024)\end{array}$ & $\begin{array}{c}-0.057^{* *} \\
(0.024)\end{array}$ \\
\hline Observations & 288981 & 154161 & 50190 & 288981 & 288981 & 154161 & 50190 & 288981 \\
\hline Adjusted $R^{2}$ & 0.137 & 0.199 & 0.319 & 0.226 & 0.140 & 0.207 & 0.323 & 0.227 \\
\hline
\end{tabular}

Notes: ${ }^{*} p<0.10,{ }^{* *} p<0.05,{ }^{* * *} p<0.01$, standard errors in parentheses, clustered by districts. Dependent variable: logarithm of a mean monthly luminosity. Time covered: January 2013 - March 2016. Standard errors clustered by districts. Excludes areas within districts that contain a segment of a contact line. All models include individual and time fixed effects. Columns All contain all regions; East Ukraine: Dnipropertovks, Kharkiv, Zaporizhia, Donetsk, Luhansk; Donbass: Donetsk, Luhansk. Columns All (RSTS) include region-specific time shocks. Sources: nighttime luminosity tiles by NOAA (2018), district borders by Hijmans, Garcia and Wieczorek [2015), urban areas by Schneider, Friedl and Potere (2009), the contact line based on UNIAN (2015) and Mediarnbo.org|(2018). 
Table 7: Impact of the Separatist-Control on Luminosity: 20-40 km away from the Contact Line, Monthly Based

\begin{tabular}{lcccccc}
\hline & \multicolumn{2}{c}{ No Controls } & & \multicolumn{2}{c}{ With Controls } \\
\cline { 2 - 3 } \cline { 5 - 6 } & No RSTS & RSTS & & No RSTS & RSTS \\
\hline DNR-control & $-0.514^{* * *}$ & $-0.507^{* * *}$ & & $-0.732^{* * *}$ & $-0.780^{* * *}$ \\
& $(0.077)$ & $(0.081)$ & & $(0.090)$ & $(0.094)$ \\
LNR-control & $-0.455^{* * *}$ & $-0.461^{* * *}$ & & $-0.442^{* * *}$ & $-0.397^{* * *}$ \\
& $(0.111)$ & $(0.115)$ & & $(0.121)$ & $(0.118)$ \\
Minsk II Effect: DNR & & & & $0.385^{* * *}$ & $0.476^{* * *}$ \\
& & & & $(0.072)$ & $(0.076)$ \\
Minsk II Effect: LNR & & & & 0.002 & -0.087 \\
& & & & $(0.059)$ & $(0.061)$ \\
All violence & & & & -0.040 & -0.038 \\
& & & & $(0.032)$ & $(0.033)$ \\
\hline Observations & 27846 & 27846 & & 27846 & 27846 \\
Adjusted $R^{2}$ & 0.329 & 0.334 & & 0.335 & 0.339 \\
\hline Notes: $p<0.10 * *$ & & & & & &
\end{tabular}

Notes: ${ }^{*} p<0.10,{ }^{* *} p<0.05,{ }^{* * *} p<0.01$, standard errors in parentheses, clustered by districts. Dependent variable: logarithm of a mean monthly luminosity. Standard errors clustered by districts. Time covered: January 2013 - March 2016. Includes only the areas within $20-40 \mathrm{~km}$ distance away from the contact line. All models include individual and time fixed effects. RSTS models include region-specific time shocks. Sources: luminosity: $\operatorname{NOAA}$ (2018), district borders: Hijmans, Garcia and Wieczorek (2015), urban areas: Schneider, Friedl and Potere (2009), the contact line: UNIAN (2015), Mediarnbo.org (2018). 
Table 8: Change of Luminosity in the DNR-controlled areas after the Trade Ban by Controls, Monthly Based

\begin{tabular}{|c|c|c|c|c|c|c|}
\hline & \multicolumn{3}{|c|}{ No DSTS } & \multicolumn{3}{|c|}{ DSTS } \\
\hline & All & NCL & $20-40 \mathrm{~km}$ & All & NCL & $20-40 \mathrm{~km}$ \\
\hline Nationalization & $\begin{array}{c}-0.337^{* * *} \\
(0.047)\end{array}$ & $\begin{array}{c}-0.197^{* * *} \\
(0.040)\end{array}$ & $\begin{array}{c}-0.196^{* *} \\
(0.068)\end{array}$ & $\begin{array}{c}-0.227^{* * *} \\
(0.066)\end{array}$ & $\begin{array}{c}-0.096^{* * *} \\
(0.000)\end{array}$ & $\begin{array}{c}-0.223^{*} \\
(0.108)\end{array}$ \\
\hline Observations & 44422 & 16996 & 10262 & 44422 & 16996 & 10262 \\
\hline Adjusted $R^{2}$ & 0.271 & 0.352 & 0.310 & 0.460 & 0.518 & 0.512 \\
\hline
\end{tabular}

Notes: ${ }^{*} p<0.10,{ }^{* *} p<0.05,{ }^{* * *} p<0.01$, standard errors in parentheses. Dependent variable: logarithm of a mean monthly luminosity. Standard errors clustered by districts. Time covered: January 2016 - December 2017. All models include individual and time fixed effects. NCL columns exclude districts containing a segment of the contact line. NCL columns contain run regressions with a subsample of cells that are 20 to $40 \mathrm{~km}$ away from the contact line. DSTS stands for district-specific time shocks. Sources (georeferenced): nighttime luminosity tiles by $\mathrm{NOAA}(2018)$, district borders by $\mathrm{Hi}-$ jmans, Garcia and Wieczorek (2015) urban areas by Schneider, Friedl and Potere (2009), the contact line based on UNIAN (2015) and Mediarnbo.org (2018), list of nationalized firms by Euromaidanpress.com (2017a) with locations manually georeferenced by the author C.1

Table 9: Production of Anthracite Coal in Donbass in Mio tons

\begin{tabular}{lccccc}
\hline Producer & $\mathbf{2 0 1 3}$ & '14 & '15 & '16 & '17 \\
\hline Donbass Total & $30.3^{1}$ & $20.6^{1}$ & - & $12.74^{2}$ & $2.4^{2}$ \\
DTEK $^{1}$ & 19.1 & 14.8 & 6.6 & 9.6 & - \\
\hline${ }^{1}$ Sources: DTEK & $(2015$, & 2016, & $2017 a)$. & & \\
${ }^{2}$ Sources: & DTEK (2017b); Golovatjuk (2017).
\end{tabular}


Table 10: Impact of the Separatist-Control on Luminosity, Monthly Based

\begin{tabular}{|c|c|c|c|c|c|c|c|c|}
\hline & \multicolumn{4}{|c|}{ No Controls } & \multicolumn{4}{|c|}{ With Controls } \\
\hline & All & East Ukraine & Donbass & All (RSTS) & All & East Ukraine & Donbass & All (RSTS) \\
\hline DNR-control & $\begin{array}{c}-1.128^{* * *} \\
(0.199)\end{array}$ & $\begin{array}{c}-1.101^{* * *} \\
(0.205)\end{array}$ & $\begin{array}{c}-0.548^{* *} \\
(0.240)\end{array}$ & $\begin{array}{c}-0.626^{* *} \\
(0.258)\end{array}$ & $\begin{array}{c}-0.784^{* * *} \\
(0.182)\end{array}$ & $\begin{array}{c}-0.772^{* * *} \\
(0.191)\end{array}$ & $\begin{array}{c}-0.537^{* *} \\
(0.242)\end{array}$ & $\begin{array}{c}-0.608^{* *} \\
(0.261)\end{array}$ \\
\hline LNR-control & $\begin{array}{c}-1.844^{* * *} \\
(0.261)\end{array}$ & $\begin{array}{c}-1.817^{* * *} \\
(0.265)\end{array}$ & $\begin{array}{c}-1.264^{* * *} \\
(0.298)\end{array}$ & $\begin{array}{c}-1.075^{* * *} \\
(0.350)\end{array}$ & $\begin{array}{c}-1.536^{* * *} \\
(0.246)\end{array}$ & $\begin{array}{c}-1.528^{* * *} \\
(0.248)\end{array}$ & $\begin{array}{c}-1.277^{* * *} \\
(0.288)\end{array}$ & $\begin{array}{c}-1.103^{* * *} \\
(0.354)\end{array}$ \\
\hline Restrictions: DNR & $\begin{array}{c}0.314 \\
(0.195)\end{array}$ & $\begin{array}{c}0.272 \\
(0.198)\end{array}$ & $\begin{array}{c}0.091 \\
(0.230)\end{array}$ & $\begin{array}{c}0.191 \\
(0.238)\end{array}$ & $\begin{array}{l}0.421^{* *} \\
(0.203)\end{array}$ & $\begin{array}{c}0.347^{*} \\
(0.205)\end{array}$ & $\begin{array}{c}0.092 \\
(0.245)\end{array}$ & $\begin{array}{c}0.198 \\
(0.254)\end{array}$ \\
\hline Restrictions: LNR & $\begin{array}{c}1.135^{* * *} \\
(0.227)\end{array}$ & $\begin{array}{c}1.093^{* * *} \\
(0.228)\end{array}$ & $\begin{array}{c}0.912^{* * *} \\
(0.253)\end{array}$ & $\begin{array}{l}0.672^{* *} \\
(0.330)\end{array}$ & $\begin{array}{c}1.286^{* * *} \\
(0.242)\end{array}$ & $\begin{array}{c}1.210^{* * *} \\
(0.244)\end{array}$ & $\begin{array}{c}0.959^{* * *} \\
(0.276)\end{array}$ & $\begin{array}{l}0.700^{*} \\
(0.370)\end{array}$ \\
\hline Crimea: Russia-control & $\begin{array}{c}0.002 \\
(0.054)\end{array}$ & & & $\begin{array}{l}0.360^{* *} \\
(0.179)\end{array}$ & $\begin{array}{c}-0.071 \\
(0.052)\end{array}$ & & & $\begin{array}{c}0.546^{* * *} \\
(0.163)\end{array}$ \\
\hline All violence & & & & & $\begin{array}{c}-0.162^{* * *} \\
(0.036)\end{array}$ & $\begin{array}{c}-0.184^{* * *} \\
(0.038)\end{array}$ & $\begin{array}{c}-0.107^{*} \\
(0.059)\end{array}$ & $\begin{array}{c}-0.114^{* *} \\
(0.057)\end{array}$ \\
\hline Observations & 250935 & 154635 & 80370 & 250935 & 250935 & 154635 & 80370 & 250935 \\
\hline Adjusted $R^{2}$ & 0.160 & 0.223 & 0.317 & 0.241 & 0.169 & 0.238 & 0.320 & 0.243 \\
\hline
\end{tabular}

Notes: ${ }^{*} p<0.10,{ }^{* *} p<0.05,{ }^{* * *} p<0.01$, standard errors in parentheses. Dependent variable: logarithm of a mean monthly luminosity. Time covered: January 2013 - March 2015. Standard errors clustered by districts. All models control for the Minsk II truce effects for DNR and LNR. All models include individual and time fixed effects. Columns All contain all regions; East Ukraine: Dnipropertovks, Kharkiv, Zaporizhia, Donetsk, Luhansk; Donbass: Donetsk, Luhansk. Columns All(RSTS) include region-specific time shocks. Sources: nighttime luminosity tiles by NOAA (2018), district borders by Hijmans, Garcia and Wieczorek (2015), urban areas by Schneider, Friedl and Potere (2009), the contact line based on [UNIAN (2015), and Mediarnbo.org (2018). 


\section{B Figures}

Figure 1: Graphical Abstract. Difference in Luminosity of the Donetsk and Luhansk Regions between January 2016 and January 2014

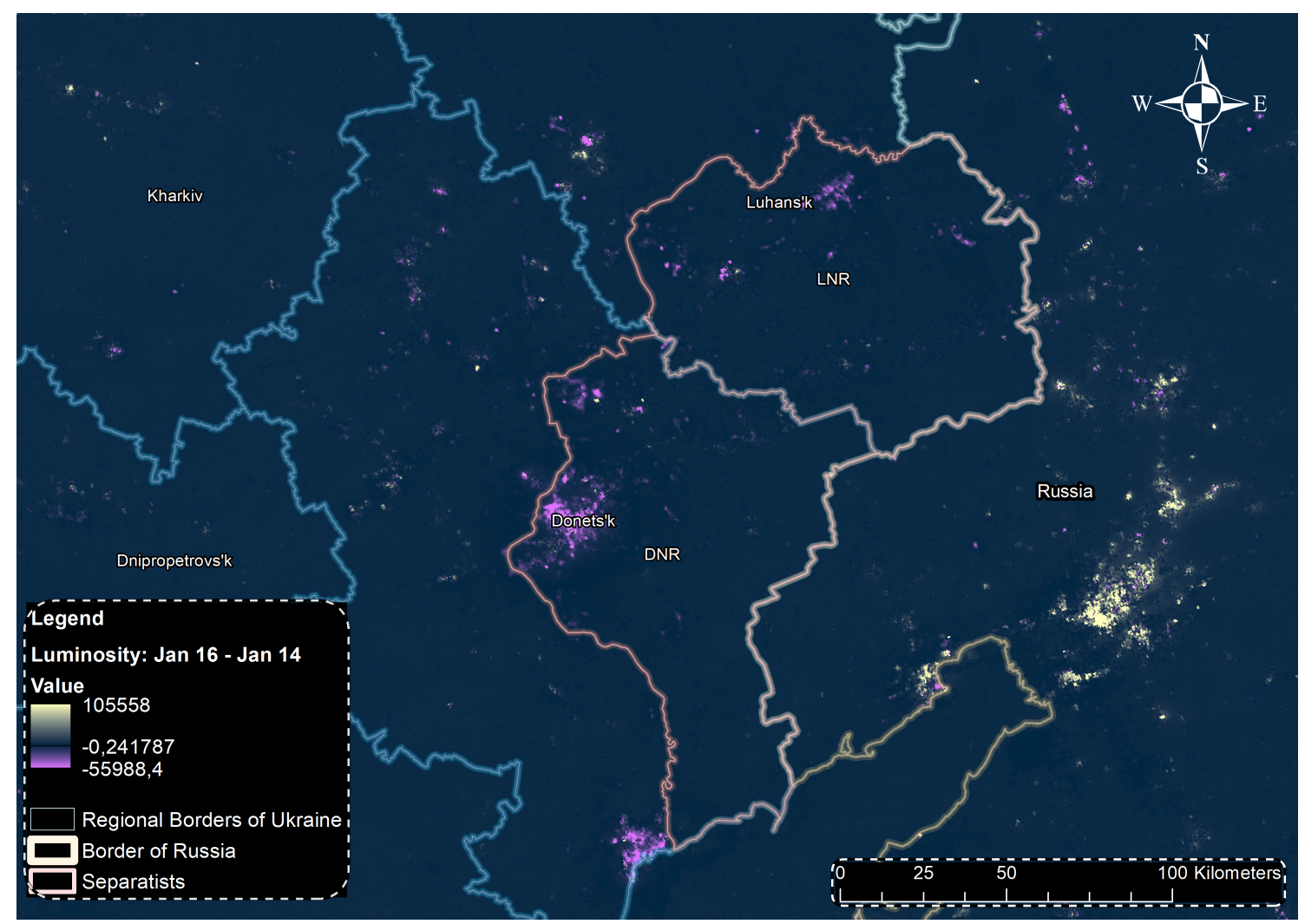

Note: Only cells outside of two standard deviations are colored yellow or violet. Yellow cells indicate an increase of luminosity, violet shows a decline in luminosity. Source: nighttime luminosity tiles by NOAA (2018), regional borders by Hijmans, Garcia and Wieczorek (2015), urban areas by Schneider, Friedl and Potere (2009), contact line georeferenced by author based on UNIAN (2015). Albers Equal Conic Projection System. 
Figure 2: Change of the Separatist-Controlled Areas

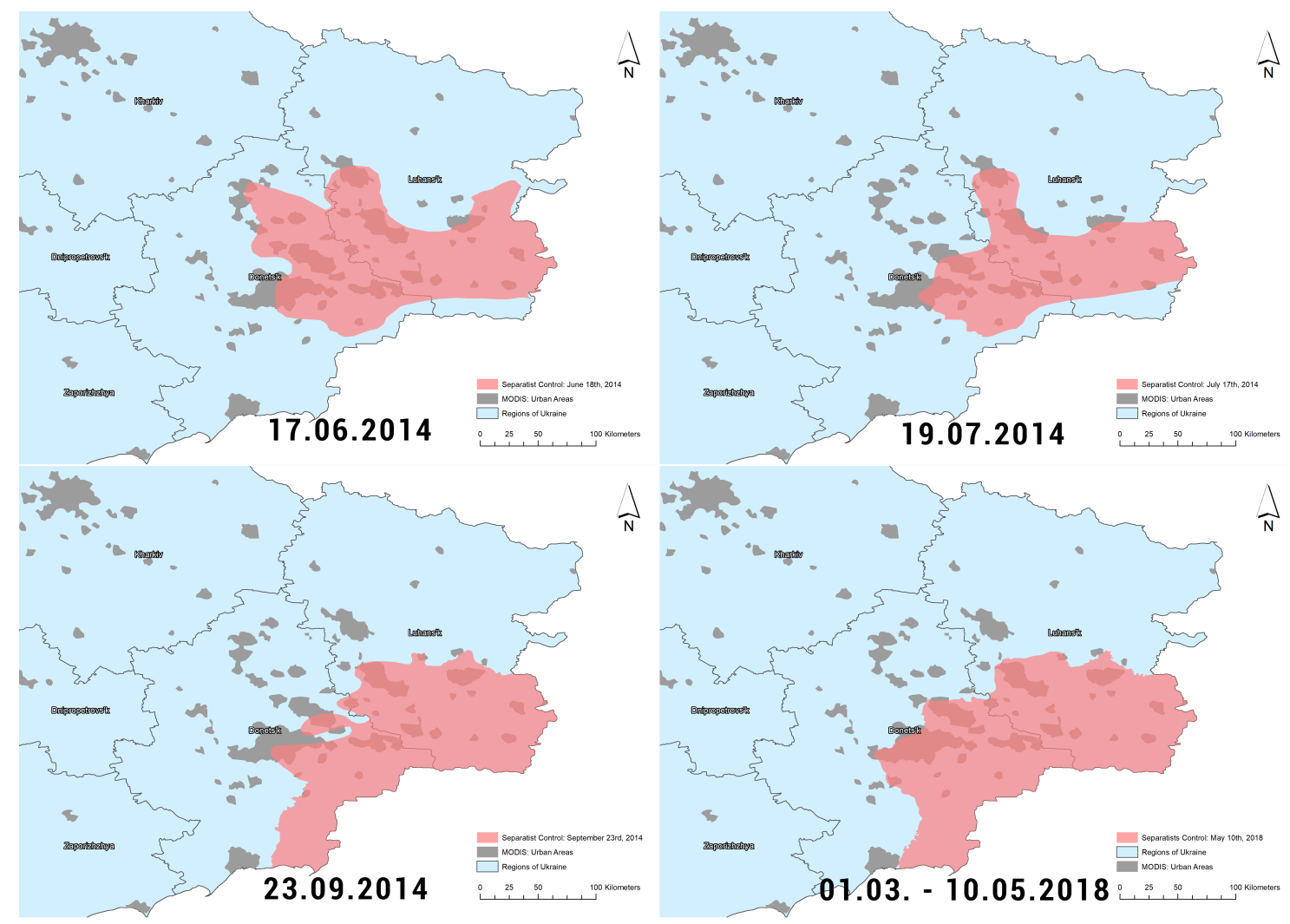

Note: Blue polygons show official Ukrainian territorial borders, red layer shows effective control by the separatists. Source: Regional borders by Hijmans, Garcia and Wieczorek (2015), separatists areas georeferenced by author based on UNIAN (2015) and maps produced by Mediarnbo.org (2018). WGS84 coordinate system. 
Figure 3: Luminosity of the Donetsk surroundings in January of 2014 - 2017 years
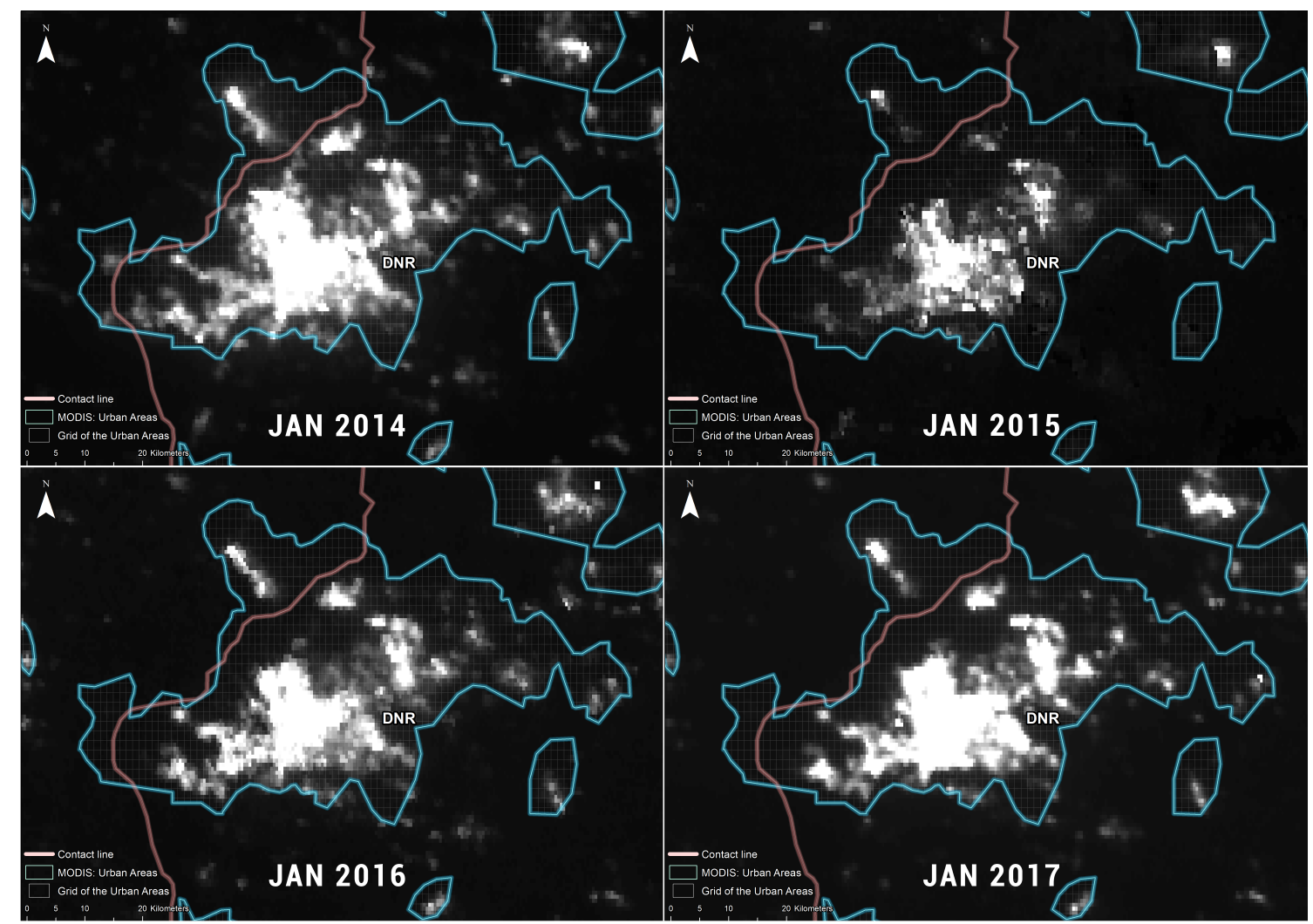

Note: Brighter values indicate greater luminosity, values above 10 are depicted with value 10 . Source: luminosity images from NOAA (2018), urban areas by Schneider, Friedl and Potere (2009), regional borders by Hijmans, Garcia and Wieczorek (2015), contact line georeferenced by author based on UNIAN (2015).

Figure 4: Change of the mean log luminosity in the Donetsk region by quarter and controlling party

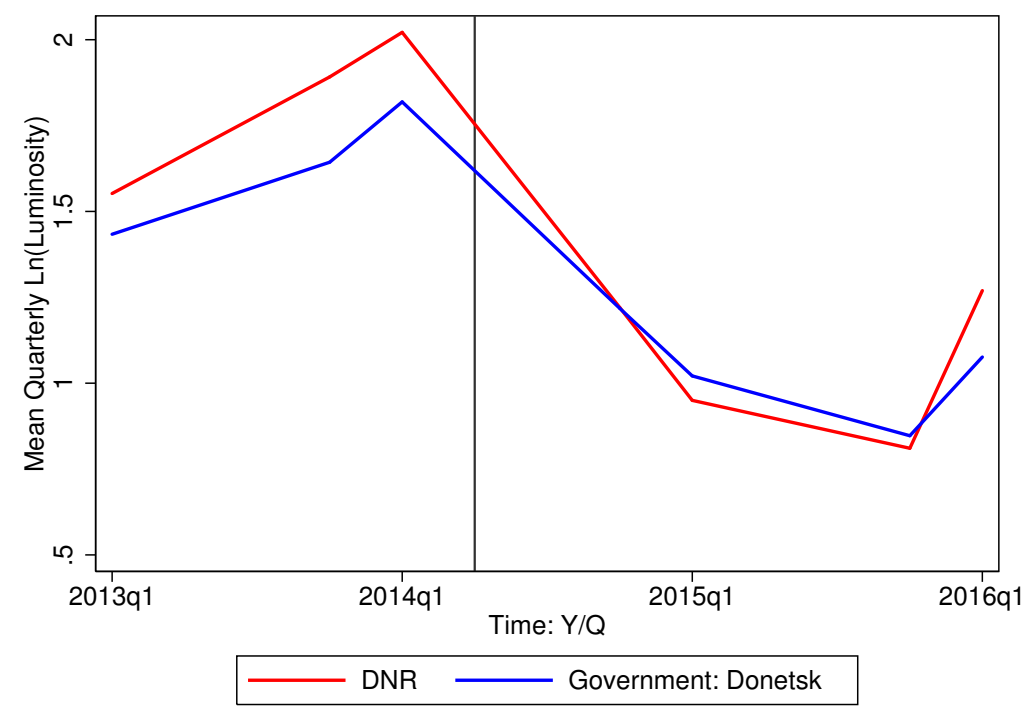

Note: Only cells in the urban areas with area $>551000$ sq.m. are considered. Vertical bar indicates start of the armed protests in Donbass. Values for every second and third quarter are interpolated on the graph but not used in regressions. Source: nighttime luminosity tiles by NOAA (2018), regional borders by Hijmans, Garcia and Wieczorek (2015), urban areas by Schneider, Friedl and Potere (2009), contact line georeferenced by author based on UNIAN (2015). 
Figure 5: Change of the mean log luminosity in the Luhansk region by quarter and controlling party

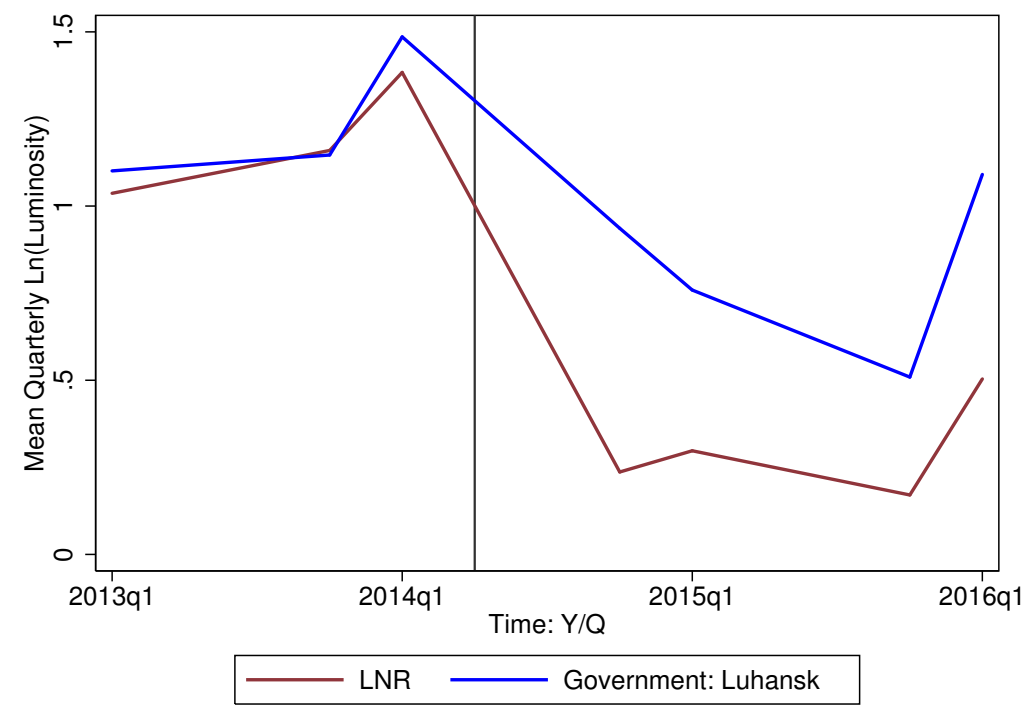

Note: Only cells in the urban areas with area $>551000$ sq.m. are considered. Vertical bar indicates start of the effective control of Russia over Crimea armed protests in Donbass. Values for every second and third quarter are interpolated on the graph but not used in regressions. Source: nighttime luminosity tiles by NOAA (2018), regional borders by Hijmans, Garcia and Wieczorek (2015), urban areas by Schneider, Friedl and Potere (2009), contact line georeferenced by author based on UNIAN (2015). 
Figure 6: Urban areas within 3.5 KM of location of nationalized firms

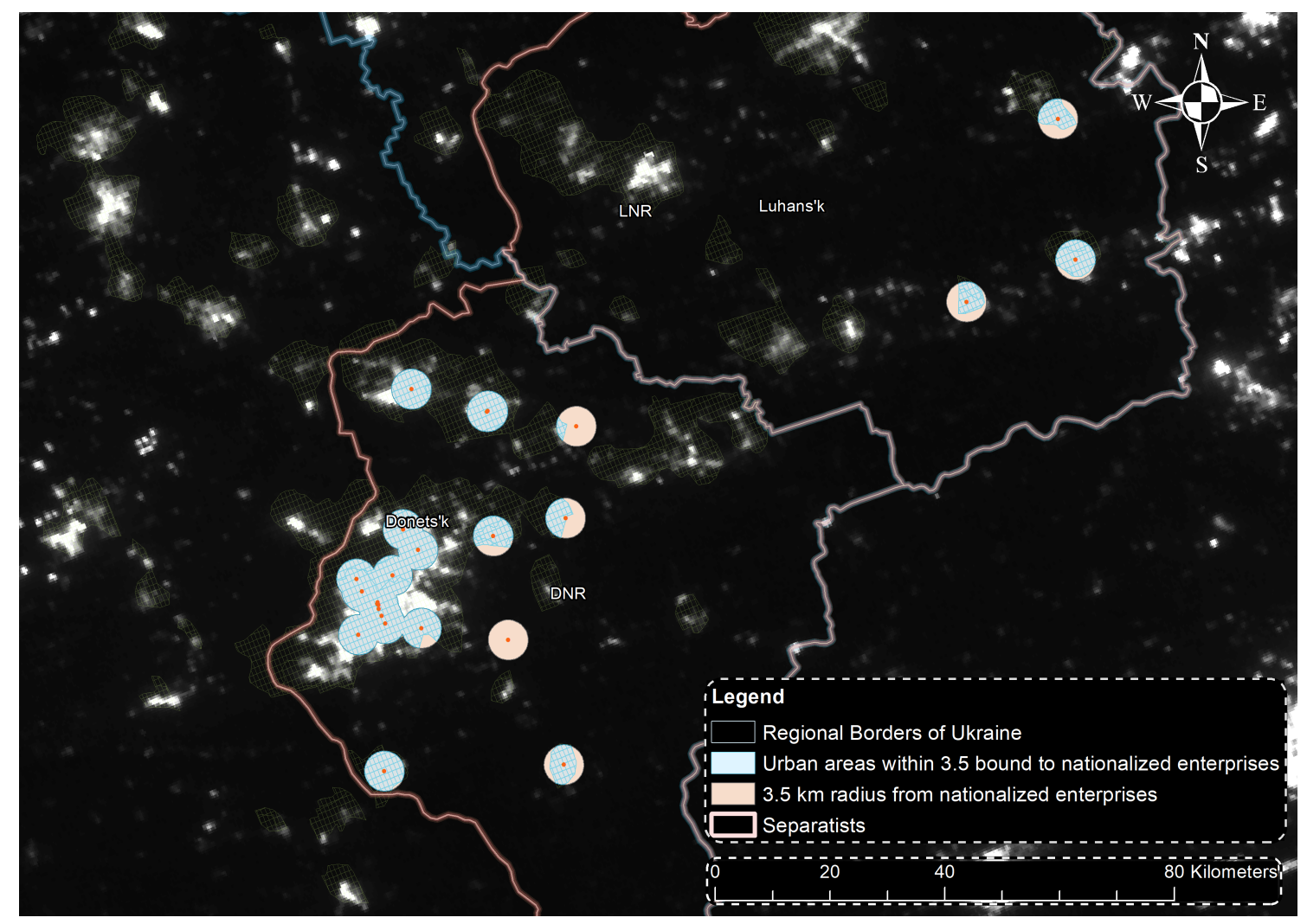

Note: Blue polygons show internationally recognized state borders of Ukraine. Red layer shows territories effectively controlled by separatists in Ukraine. Source: nighttime luminosity tiles by NOAA (2018), regional borders by Hijmans, Garcia and Wieczorek (2015), urban areas by Schneider, Friedl and Potere (2009), contact line georeferenced by author based on UNIAN (2015), location of the nationalized enterprises Euromaidanpress.com (2017a). WGS84 coordinate system. 
Figure 7: Change of the mean log luminosity in the separatist-controlled region of Donetsk by quarter

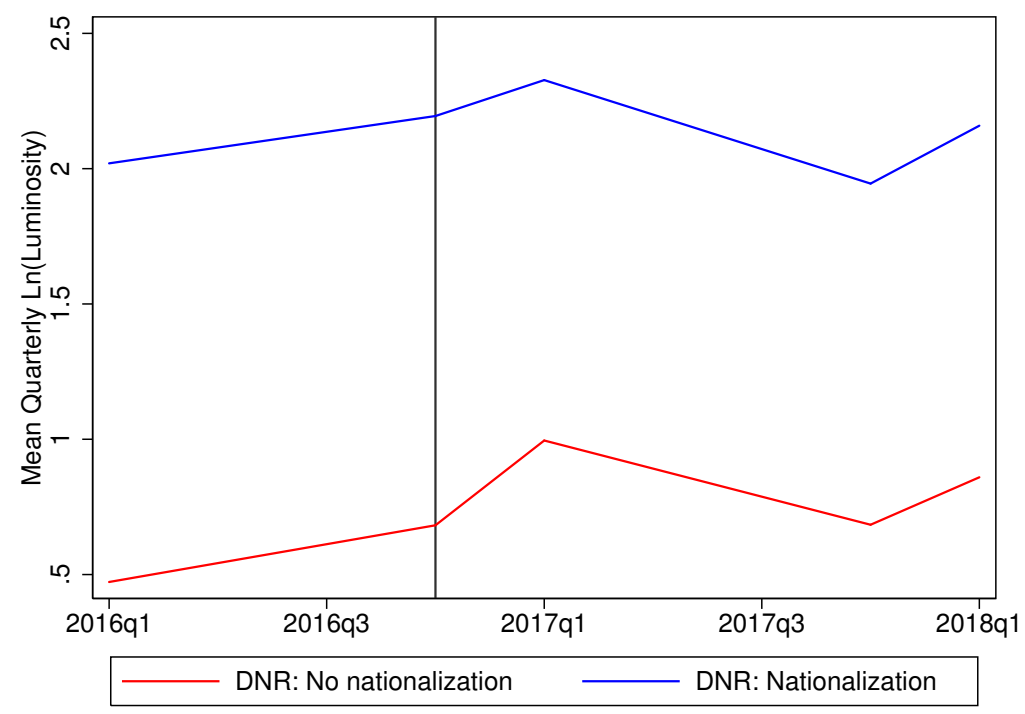

Note: Only cells in the urban areas with area $>551000$ sq.m. are considered. Vertical bar indicates the nationalization of the largest private enterprises and a full trade ban by the Ukrainian government. Values for every second and third quarter are interpolated on the graph but not used in regressions. Source: nighttime luminosity tiles by $\mathrm{NOAA}(2018)$, regional borders by $\mathrm{Hi}-$ jmans, Garcia and Wieczorek (2015), urban areas by Schneider, Friedl and Potere (2009), contact line georeferenced by author based on UNIAN (2015), location of the nationalized enterprises Euromaidanpress.com (2017a).

Figure 8: The Number of Internally Displaced Persons and Battle Events in the Cities Populated Areas of Donetsk and Luhansk

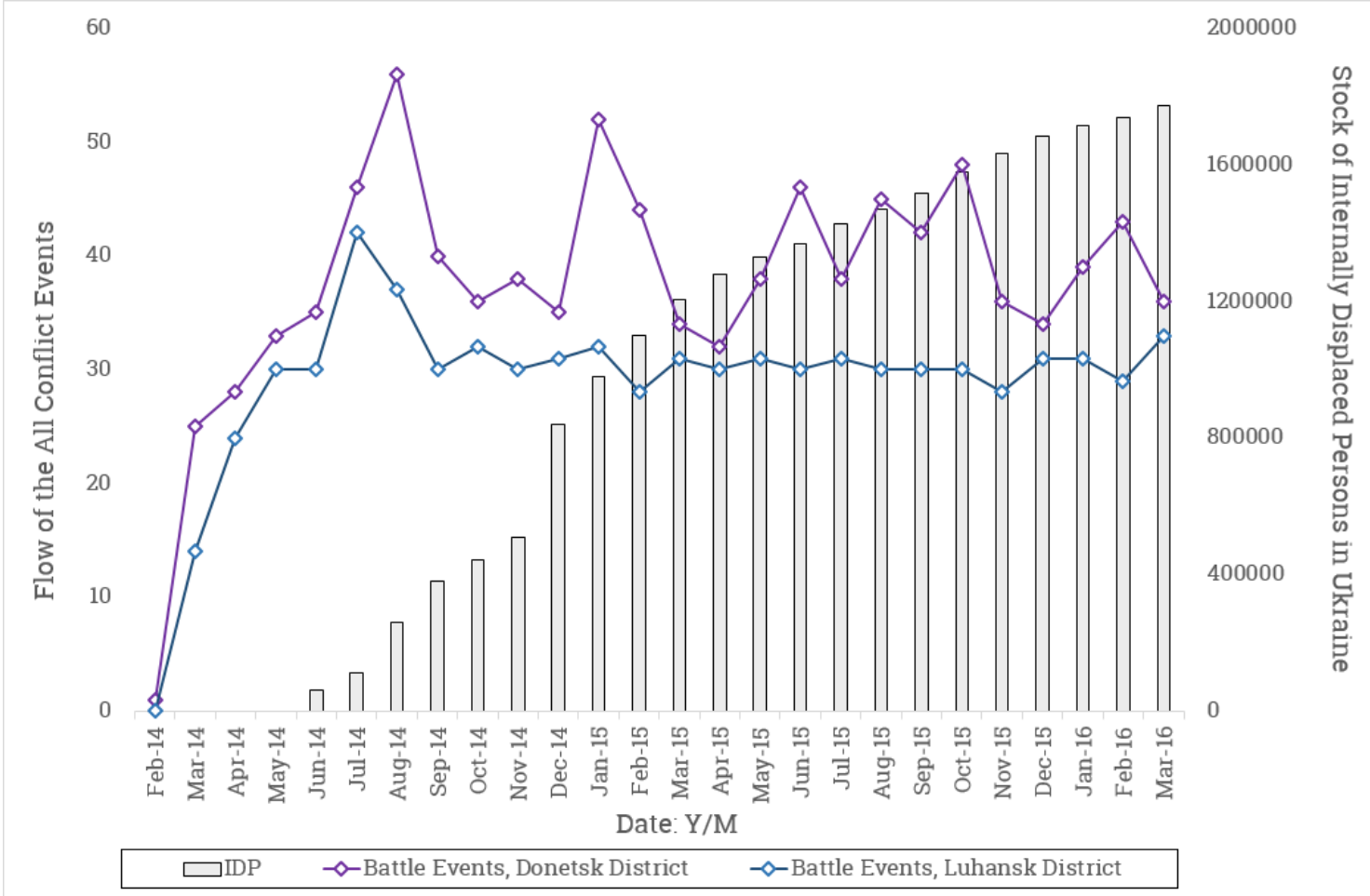

Note: IDPs include both IDPs of East Ukraine and Crimea. Source: Number of Internally Displaced Persons: June - November 2014 by OCHA (2014), the rest by Ministry of Social Policy of Ukraine, Battle Events: Zhukov, Davenport and Kostyuk (2017). 



\section{Dying Light: The Online-Project}

Description: The author encourages the reader to visit the online-project dedicated to the background and onset of the war in Ukraine. The project combines the results of the paper together with the grassroots evidence brought by the photo series and the video footage to illuminate the image of the war in Ukraine. 



\section{WIIW WORKING PAPERS PUBLISHED SINCE 2016}

For current updates and summaries see also wiiw's website at www.wiiw.ac.at

No. 161 Artem Kochnev: Dying Light: War and Trade of the Separatist-Controlled Areas of Ukraine, January 2019

No. 160 Mahdi Ghodsi: How Do Technical Barriers to Trade Affect Foreign Direct Investment? Evidence from Central, East and Southeast Europe, January 2019

No. 159 Sandra M. Leitner: Eco-Innovation: Drivers, Barriers and Effects - A European Perspective, December 2018

No. 158 Michael Landesmann and Sandra M. Leitner: Immigration and Innovation: Do High-skilled Third Country (i.e. NonEU) Migrants Contribute to Productivity Growth?, December 2018

No. 157 Claudius Gräbner, Philipp Heimberger, Jakob Kapeller and Florian Springholz: Measuring Economic Openness: A Review of Existing Measures and Empirical Practices, December 2018

No. 156 Michael Landesmann and Sandra M. Leitner: Immigration and Offshoring: Two Forces of 'Globalisation' and Their Impact on Labour Markets in Western Europe: 2005-2014, November 2018

No. 155 Sebastian Leitner: Factors Driving Wealth Inequality in European Countries, November 2018

No. 154 Stefan Jestl, Sandra M. Leitner and Sebastian Leitner: The Relative Impact of Different Forces of Globalisation on Wage Inequality: A Fresh Look at the EU Experience, November 2018

No. 153 Mahdi Ghodsi and Robert Stehrer: Avoiding and Escaping the 'Commodity Trap' in Development, November 2018

No. 152 Stefan Jestl: Inheritance Tax Regimes: A Comparison, November 2018

No. 151 Mahdi Ghodsi: Is Austria's Economy Locked-in in the CESEE Region? Austria's Competitiveness at the Microlevel, October 2018

No. 150 Amat Adarov: Eurasian Economic Integration: Impact Evaluation Using the Gravity Model and the Synthetic Control Methods, September 2018

No. 149 Philipp Heimberger: What Explains Austria's Export Market Performance? Evidence Based on Estimating an Export Model over 1997-2016, September 2018

No. 148 Oliver Reiter and Robert Stehrer: Trade Policies and Integration of the Western Balkans, May 2018

No. 147 Philipp Heimberger: The Dynamic Effects of Fiscal Consolidation Episodes on Income Inequality: Evidence for 17 OECD Countries over 1978-2013, April 2018

No. 146 Mahdi Ghodsi: The Impact of Chinese Technical Barriers to Trade on its Manufacturing Imports, March 2018

No. 145 Amat Adarov: Financial Cycles Around the World, March 2018

No. 144 Mario Holzner: Corporatism and the Labour Income Share. Econometric Investigation into the Impact of Institutions on the Wage Share of Industrialised Nations, March 2018

No. 143 Claudius Gräbner, Philipp Heimberger, Jakob Kapeller, Bernhard Schütz: Structural Change in Times of Increasing Openness: Assessing Path Dependency in European Economic Integration, March 2018

No. 142 Loredana Fattorini, Mahdi Ghodsi and Armando Rungi: Cohesion Policy Meets Heterogeneous Firms, March 2018

No. $141 \quad$ Neil Foster-McGregor, Michael Landesmann and Isilda Mara: Migration and FDI Flows, March 2018

No. 140 Amat Adarov: Financial Cycles in Credit, Housing and Capital Markets: Evidence from Systemic Economies, December 2017

No. 139 Eddy Bekkers, Michael Landesmann and Indre Macskasi: Trade in Services versus Trade in Manufactures: The Relation between the Role of Tacit Knowledge, the Scope for Catch-up, and Income Elasticity, December 2017

No. 138 Roman Stöllinger: Global Value Chains and Structural Upgrading, September 2017

No. 137 Stefan Jestl, Mathias Moser and Anna K. Raggl: Can't Keep Up with the Joneses: How Relative Deprivation Pushes Internal Migration in Austria, September 2017

No. 136 Claudius Gräbner, Philipp Heimberger, Jakob Kapeller and Bernhard Schütz: Is Europe Disintegrating? Macroeconomic Divergence, Structural Polarisation, Trade and Fragility, September 2017

No. 135 Mahdi Ghodsi and Robert Stehrer: EU Trade Regulations and Imports of Hygienic Poultry, April 2017

No. 134 Roman Stöllinger: Tradability of Output and the Current Account: An Empirical Investigation for Europe, January 2017

No. 133 Tomislav Globan: Financial Supply Index and Financial Supply Cycles in New EU Member States, December 2016

No. 132 Mahdi Ghodsi, Julia Grübler and Robert Stehrer: Import Demand Elasticities Revisited, November 2016

No. 131 Leon Podkaminer: Has Trade Been Driving Global Economic Growth?, October 2016

No. 130 Philipp Heimberger: Did Fiscal Consolidation Cause the Double-Dip Recession in the Euro Area?, October 2016

No. 129 Julia Grübler, Mahdi Ghodsi and Robert Stehrer: Estimating Importer-Specific Ad Valorem Equivalents of NonTariff Measures, September 2016

No. 128 Sebastian Leitner and Robert Stehrer: Development of Public Spending Structures in the EU Member States: Social Investment and its Impact on Social Outcomes, August 2016

No. 127 Roman Stöllinger: Structural Change and Global Value Chains in the EU, July 2016 

IMPRESSUM

Herausgeber, Verleger, Eigentümer und Hersteller:

Verein "Wiener Institut für Internationale Wirtschaftsvergleiche“ (wiiw),

Wien 6, Rahlgasse 3

ZVR-Zahl: 329995655

Postanschrift: A 1060 Wien, Rahlgasse 3, Tel: [+431] 53366 10, Telefax: [+431] 533661050 Internet Homepage: www.wiiw.ac.at

Nachdruck nur auszugsweise und mit genauer Quellenangabe gestattet.

Offenlegung nach § 25 Mediengesetz: Medieninhaber (Verleger): Verein "Wiener Institut für Internationale Wirtschaftsvergleiche", A 1060 Wien, Rahlgasse 3. Vereinszweck: Analyse der wirtschaftlichen Entwicklung der zentral- und osteuropäischen Länder sowie anderer Transformationswirtschaften sowohl mittels empirischer als auch theoretischer Studien und ihre Veröffentlichung; Erbringung von Beratungsleistungen für Regierungs- und Verwaltungsstellen, Firmen und Institutionen. 
wiiw

wiiw.ac.at 